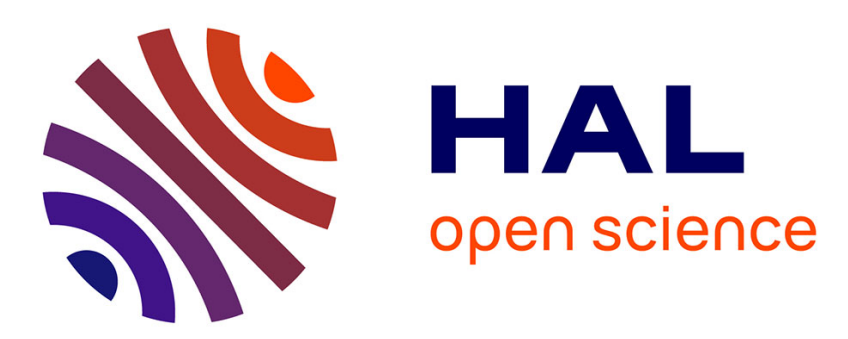

\title{
New insights into the phenotypes of atopic dermatitis linked with allergies and asthma in children: An overview
}

\author{
Flore Amat, A. Soria, P. Tallon, M. Bourgoin-Heck, N. Lambert, A.
}

Deschildre, J. Just

\section{To cite this version:}

Flore Amat, A. Soria, P. Tallon, M. Bourgoin-Heck, N. Lambert, et al.. New insights into the phenotypes of atopic dermatitis linked with allergies and asthma in children: An overview. Clinical and Experimental Allergy, 2018, 48 (8), pp.919-934. 10.1111/cea.13156 . hal-02404738

\section{HAL Id: hal-02404738 \\ https://hal.sorbonne-universite.fr/hal-02404738}

Submitted on 11 Dec 2019

HAL is a multi-disciplinary open access archive for the deposit and dissemination of scientific research documents, whether they are published or not. The documents may come from teaching and research institutions in France or abroad, or from public or private research centers.
L'archive ouverte pluridisciplinaire HAL, est destinée au dépôt et à la diffusion de documents scientifiques de niveau recherche, publiés ou non, émanant des établissements d'enseignement et de recherche français ou étrangers, des laboratoires publics ou privés. 
New insights into the phenotypes of atopic dermatitis linked with allergies and asthma in children: an overview

Running head: phenotypes of atopic dermatitis in children

F Amat ${ }^{1,2,3}$, A Soria ${ }^{2,4}$, P Tallon ${ }^{1,2}$, M Bourgoin-Heck ${ }^{1}$, N Lambert $^{1,3}$, A Deschildre ${ }^{5}$, J Just $^{1,2,3^{*}}$

${ }^{1}$ Department of Allergology-Centre de l'Asthme et des Allergies, Hôpital d'Enfants Armand Trousseau, Assistance Publique-Hôpitaux de Paris, Paris, France

${ }^{2}$ UPMC Univ Paris 06, Sorbonne Universités, Paris, France

3 Equipe EPAR, Institut Pierre Louis d'Epidémiologie et de Santé Publique, UMR_S1136, INSERM, Paris, France

${ }^{4}$ Department of Dermatology and Allergology, Hôpital Tenon, APHP Paris, France ; Inserm, Centre d'Immunologie et des Maladies Infectieuses (Cimi-Paris), UMR 1135, Paris, France ${ }^{5}$ CHRU Lille, Pediatric Pulmonology and Allergy Department, Hôpital Jeanne de Flandre, F59000 Lille, France

* Corresponding author:

Department of Allergology—Centre de l'Asthme et des Allergies, Hôpital d'Enfants Armand Trousseau

26 avenue du Dr Arnold Netter

75012 Paris, France

Tel + 33144736847

jocelyne.just@aphp.fr 


\section{Abstract (251/300 words)}

Atopic dermatitis (AD) is a complex disease with multiple causes and complex mechanistic pathways according to age of onset, severity of the illness, ethnic modifiers, response to therapy, and triggers. A group of difficult-to-manage patients characterized by early-onset AD and severe lifelong disease associated with allergic asthma and/or food allergy, has been identified. In this paper, we focus on these severe phenotypes, analyzing their links with other atopic comorbidities, and taking into account the results from recent cohort studies and metaanalyses. The main hypothesis that is currently proposed to explain the onset of allergic diseases is an epithelial barrier defect. Thus, the atopic march could correspond to an epithelial dysfunction, self-sustained by a secondary allergenic sensitization, explaining the transition from $\mathrm{AD}$ to allergic asthma. Furthermore, $\mathrm{AD}$ severity seems to be a risk factor for associated food allergy. Results from population-based, birth and patient cohorts show that early-onset and severe AD, male gender, parental history of asthma, and early and multiple sensitizations are risk factors leading to the atopic march and the development of asthma. The importance of environmental factors should be recognized in these high-risk children and prevention programs adapted accordingly. Effective targeted therapies to restore both barrier function and to control inflammation are necessary; early emollient therapy is an important approach to prevent AD in high-risk children. Clinicians should also keep in mind the specific risk of atopic comorbidities in case of filaggrin loss-of-function mutations and the rare phenotypes of orphan syndromes due to heritable mutations in skin barrier components. 


\section{Manuscript (4381/4000 w.)}

\section{Introduction}

Atopic dermatitis (AD) is the most common chronic inflammatory disorder of the skin in children. Although not life-threatening, AD hugely alters quality of life due to pruritus that may constitute a disabling condition affecting sleep as well as daily or social activities ${ }^{1,2}$. Furthermore, the financial burden of the disease should not be underestimated: for example, in the United Kingdom AD costs the healthcare system around $£ 125$ million annually ${ }^{2}$. Evidence from the ISAAC Study and other population-based cohorts shows that AD affects more than $20 \%$ of children in industrialized countries ${ }^{3,4}$. Although primarily defined by clinical criteria $^{5,6}$, it is now recognized that $\mathrm{AD}$ is a complex disease with multiple causes and complex mechanistic pathways according to age of onset, severity of the illness, ethnic modifiers, response to therapy, and triggers (including infections, allergens, stress, and irritants). Approximately one third of patients with $\mathrm{AD}$ have sensitization to allergens ${ }^{4}$. Most infants who present with mild AD will outgrow their skin disease later in life, and overall less than $5 \%$ of childhood AD will persist into adulthood ${ }^{4}$. However, a group of difficult-tomanage patients with early-onset and severe lifelong AD associated with allergic asthma and/or food allergy (FA) has been identified ${ }^{7}$. In this general review, we will focus on these severe phenotypes, analyzing their links with other atopic comorbidities, and taking into account the results from recent cohort studies and meta-analyses. We will first describe the criteria mainly used to define $\mathrm{AD}$, then the pathophysiological pathways suspected to lead to sensitization and asthma, the particular phenotypes due to ethnic background, the epidemiological links between $\mathrm{AD}$, other atopic comorbidities, and some orphan genetic diseases, and finally the last results on prevention and treatment.

\section{Methodology}


We searched the Medline database for terms included in the Cochrane Skin Group strategy for $\mathrm{AD}^{8}$ and terms describing FA, food hypersensitivity, and food/aeroallergen sensitization, respiratory allergies, and asthma. The terms used to identify studies focusing on AD are described in Table 1.

Four authors (F.A., A.S., A.D., and J.J.) then independently screened the studies to select those published in international peer-reviewed journals. Discrepancies in the assessment were resolved through discussion among the four authors.

\section{Particular issues due to various definitions of $A D$}

The United Kingdom Working Party (UKWP) defined the following diagnostic criteria for clinical research: “AD is an itchy skin disease (located on bending folds in children older than 4 years, or on limb convexities, cheeks and forehead in younger children), accompanied by

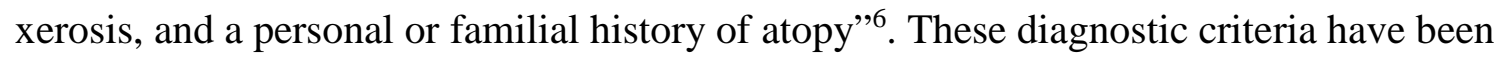
validated both in hospital and community settings and have been used in many epidemiological studies worldwide. They constitute a refinement of the Hanifin and Rajka diagnostic criteria, developed in the 1980s, which defined AD as having at least three of the following criteria: pruritus, lichenification, a chronically relapsing course, personal or familial history of atopy ${ }^{5}$.

However, some of the epidemiological studies included in this review have used other criteria to define AD or atopic eczema, and readers should be aware of these methodological differences while interpreting the findings.

Finally, a multidisciplinary team of experts addressing therapies for moderate-to-severe AD has recently reached aa high level of consensus to define AD as a chronic, relapsing, noncontagious, pruritic inflammatory skin disease that occurs more commonly in children. They go further in stating that $\mathrm{AD}$ is often, but not exclusively, associated with allergenic sensitization with elevated serum IgE levels and a personal or family history of atopic 
background (i.e., allergic asthma, allergic rhinoconjunctivitis, and/or FA). The experts state that a diagnosis of $\mathrm{AD}$ should not be ruled out in individuals lacking evidence of sensitization, and that allergic or irritant contact dermatitis and other forms of eczematous dermatitis (dyshidrotic eczema, nummular dermatitis, seborrheic eczema, etc.) may occur concomitantly or independently with $\mathrm{AD}^{9}$.

The main criteria used to define AD throughout the studies retained for this review are summarized in Table 2.

The main studies cited in this review are summarized in Tables 3 and 4.

\section{Pathophysiology of AD and link with sensitization}

The main current accepted hypothesis to explain the onset of AD is an epithelial barrier defect associated with a dysfunction of the skin's innate and adaptive immune systems, and dysbiosis. Thus, the atopic march could correspond to an epithelial dysfunction, self-sustained by a secondary allergenic sensitization, explaining the transition from AD to allergic asthma. The skin represents the interface between the body, especially lymphoid tissues, and the surrounding environment, preventing antigens from irrupting into circulating blood. Injuries induced by scratching or irritant topics could increase the absorption of allergens through the skin $^{10}$ thus facilitating sensitization and promoting skin inflammation. Skin barrier dysfunction is due to multiple abnormalities, including in particular a low level of lipids (ceramides and sphingosines) facilitating dysbiosis ${ }^{11}$, and abnormal keratinization due to dysfunctional filaggrin. Filaggrin, a protein that surrounds the keratin filaments, and keratinocytes are essential components of the stratum corneum ${ }^{12}$, which acts as a barrier to water loss. Corneocytes, resulting from a keratinocyte differentiation process, are anucleated cells filled with keratin filaments as well as amino acids and other small molecules (collectively referred to as natural moisturizing factor: NMF) derived from the breakdown of filaggrin. 
Filaggrin gene expression is linked to skin barrier function and is associated with the risk of AD. Ziyab et al found that increased filaggrin expression was associated with a reduced risk of $\mathrm{AD}$ during the first year of life $\mathrm{e}^{13}$.

Early studies ${ }^{14-16}$ reported filaggrin loss-of-function mutations in about $20 \%$ of European patients with $\mathrm{AD}$, but other filaggrin mutations have been detected in people of Asian origin $^{17}$. The presence of filaggrin mutations has been related to more severe phenotypes (as measured by the SCORAD index) and to allergic sensitization to house dust mites and cat dander, for example $\mathrm{e}^{18}$.

During AD, both lesional and non-lesional skin exhibit a defective permeability barrier reflected by an increase in transepidermal water loss (TEWL) that persists even between flares ${ }^{19}$. TEWL is associated with a reduction in hydration of the stratum corneum and is positively correlated with $\mathrm{AD}$ severity ${ }^{20}$. In a mouse model, dysfunction of the epidermal barrier, and especially the stratum corneum, has been shown to induce transcutaneous sensitization and increase production of interleukin-4 and specific IgE independently of allergens or genetic background ${ }^{21}$. Furthermore, Kelleher et al have demonstrated that TEWL at birth is linked to food sensitization and food allergy at 2 years of age, supporting the concept of transcutaneous sensitization ${ }^{22}$.

In $\mathrm{AD}$, keratinocytes also respond abnormally to environmental irritants by producing Th2 cytokines such as interleukin-13 (IL-13) and thymic stromal lymphopoietin (TSLP) ${ }^{23}$. This production of Th2 cells contributes to a decreased expression of filaggrin and of antimicrobial peptides promoting colonization of Staphylococcus Aureus (S Aureus) ${ }^{24}$ which in turn promotes excessive production of TSLP ${ }^{25}$. TSLP may act as a trigger of bronchial hyperreactivity; when deleted in mice, the atopic march is stemmed, suggesting that TSLP may be a link between AD and asthma ${ }^{26}$. 
Finally, there is a specific interaction between $\mathrm{AD}$ and microorganisms. This is reflected by the strong relationship between AD severity and the toxins secreted by $S$ Aureus. In a mouse model, staphylococcal enterotoxin B has been shown to have a synergic effect with allergenic exposure in $\mathrm{AD}$ severity leading to increased bronchial hyper-reactivity after inhaled challenge ${ }^{27}$. Furthermore, abnormal cutaneous response to microorganisms in children with $\mathrm{AD}$ could be involved in the pathways leading to asthma and allergies ${ }^{28}$.

\section{Specific phenotypes due to ethnic background}

It is becoming increasingly accepted that there are ethnic differences in the phenotypic expression of AD. Noda et al, for instance, compared genomic profiling and immunohistochemistry on lesional and non-lesional biopsy specimens from 27 patients of Asian descent and 25 of European American descent. Although disease severity was similar between the groups, prominent epidermal hyperplasia, frequent parakeratosis, higher Th17 activation, and a strong Th2 component were characteristic of lesional epidermis in the Asian patients ${ }^{29}$. These histological and immunological differences are reflected in phenotypic differences in clinical practice: patients of Asian descent have more well-demarcated, erythematous, plaque-like skin lesions; patients of European descent have ill-defined, less elevated erythematous skin lesions; and patients of African descent have more lichenified skin lesions $^{30}$. Furthermore, the prevalence of atopic diseases varies according to ethnic background. Severe AD has a higher prevalence in African Americans than in European Americans $^{31,32}$. Whether this disparity stems from true genetic or ethnic-specific environmental risk factors or both, is unknown. Thus far, most genetic studies on atopic diseases have used populations of European descent, limiting their generalizability. It has been well demonstrated that filaggrin mutations are population specific, and that common filaggrin mutations in patients with severe $\mathrm{AD}$ of European descent are absent in patients of African descent. The fact that ethnic minorities often have a lower socio-economic status and 
are more often associated with poor environmental conditions, may also have a direct effect on the development of atopic disorders and this needs to be carefully adjusted for in statistical analyses $^{33}$.

\section{Link between AD phenotypes and food sensitization and FA}

\section{AD phenotypes and risk of food sensitization}

$\mathrm{AD}$ is often linked with IgE-mediated FA: it is thought that food allergen recognition through antigen-presenting cells in eczematous skin is an important mediator of food sensitization. A recent meta-analysis performed by Tsakok et al showed that food sensitization was 6 times higher at 3 months of age in children with AD compared to controls ${ }^{34}$ in population-based studies. This risk has been shown to persist throughout infancy in high-risk cohort studies ${ }^{35,36}$. In the ORCA (Observatory of Risks linked with Cutaneous Atopy) Study, hen’s egg, cow's milk, and peanut accounted for $95 \%$ of overall food sensitization ${ }^{37}$. Birth cohort studies show similar results, although the order of allergens differ slightly from one country to another and from one age range to another: mainly egg (21\%) in 2-year-olds from the Barn (Children’s) Allergy Milieu Stockholm Epidemiology (BAMSE) cohort ${ }^{38}$; mainly milk (48\%) in Italy and peanut (45\%) in Australia in children from the Early Prevention of Asthma in Atopic Children Study Group cohorts (mean age 17.6 months) ${ }^{39}$. Peanut sensitization seems to be more strongly associated with $\mathrm{AD}$ in older children ${ }^{40}$, or if $\mathrm{AD}$ is severe ${ }^{41}$ or associated with previous egg sensitization ${ }^{42}$. Egg sensitization is associated with $\mathrm{AD}$ in most of the studies $^{43,44}$, with ORs ranging from 4.73 to $12.76^{34}$. Food sensitization is particularly frequent when $\mathrm{AD}$ is severe ${ }^{35}$, as demonstrated in the LEAP Study ${ }^{42}$. Loo et al have also shown in the Growing Up in Singapore Towards healthy Outcomes birth cohort (GUSTO), including 792 infants, that an onset of AD before the age of 6 months was significantly associated with food sensitization at 18 months (OR 46.51; IC95\%: 3.44-628.81, $\mathrm{p}<0.01)^{45}$. These results are consistent with a previous Swedish patient cohort study ${ }^{46}$. 


\section{AD phenotypes and risk of FA}

Although food sensitization is frequent in children with early-onset AD, FA is not systematic. In the ORCA Study, where all the children had early-onset ( $<12$ months) moderate to severe $\mathrm{AD}, 57.5 \%$ of them had food sensitization at baseline, whereas FA was reported in only $11.7 \%{ }^{47}$. In this study, FA was not defined by food challenge but by relevant allergic symptoms following consumption of a food allergen, associated with an IgE sensitization to the same allergen, and confirmed by an allergist. Nevertheless, the results were very similar to those from the Danish Allergy Research Cohort (DARC) which monitored children from the age of 3 months to 6 years. Children with positive skin prick tests or with positive specific IgEs to food allergens, or with a history of reported adverse reactions to food, were investigated with food challenges: of the 122 children with $A D, 52 \%$ were sensitized to food but only $15 \%$ of these children had a positive food challenge ${ }^{44}$. Results from the Isle of Wight birth cohort support the finding of a temporal sequence between AD and FA, with the prevalence of FA in10-year-olds being twice as high as in 1-year-olds in children with filaggrin loss-of-function mutations ${ }^{48}$.

Severe AD seems to be a risk factor for associated FA, as demonstrated recently in a South African patient cohort ${ }^{49}$. Early childhood AD increases the risk of food sensitization during life as a subsequent complication in genetically predisposed children carrying filaggrin lossof-function mutations ${ }^{48,50}$. The risk of sensitization through the skin is higher when filaggrin is absent or deficient in murine models ${ }^{51}$. Thus, filaggrin genetic deficiency should be explored in children with early-onset and severe $\mathrm{AD}^{52}$. Independently from filaggrin genetic deficiencies, genetic and ethnic predispositions for a particular form of AD linked with food sensitization and then FA are probable. Gray et al in South Africa, showed high rates of food sensitization and, most of all, high rates of challenge-confirmed FA (44\%) in a cohort of black or mixed-race children with moderate to severe $\mathrm{AD}^{49}$. Ashley et al recently showed that the 
rs9325071 variant of the skin barrier function gene SPINK5 may be a risk factor for both FA and $\mathrm{AD}^{53}$.

\section{Risk factors for the “atopic march”, a "particular phenotype of AD” (Figure 1)}

$\mathrm{AD}$ is considered to be the first step towards asthma. The term "atopic march" suggests a chronological sequence during childhood, with AD predating other manifestations of atopy such as asthma and allergic rhinitis. Many studies describe this particular trajectory ${ }^{52}$. In a birth-cohort study, Rhodes et al demonstrated the time course of atopic diseases from childhood to adulthood ${ }^{54}$. Abnormal reactivity to environmental triggers, present both in AD and asthma, suggest shared pathophysiological pathways. However, whether it is a temporal sequence between the diseases or a predetermined phenotype of multiple atopic comorbidities remains a matter of debate ${ }^{55}$. Results from the German Multicenter Atopy Study (MAS) birth cohort do not support the hypothesis of a chronological sequence of atopic diseases ${ }^{56}$. In this study, 1314 infants were recruited including 499 at risk of atopy due to familial history. Among them, only those who had early-onset AD (before 2 years), and early-onset wheezing (before 3 years), had an increased risk of asthma at 7 years. Conversely, most of the children who had early-onset AD without wheezing did not have an increased risk of asthma. Half of the children with early-onset $\mathrm{AD}$ already had recurrent wheezing far before the onset of $\mathrm{AD}$. Thus, the link between $\mathrm{AD}$ and asthma seems more complex than ever thought before.

Furthermore, it has been well established that the atopic march only concerns from one third to a half of the children with $\mathrm{AD}^{7}$. Early-onset, severity, gender, multiple sensitization, environmental and genetic factors have been identified as risk factors.

\section{Early onset of $A D$}

Early-onset $\mathrm{AD}$ is a risk factor for school-age asthma. In a cohort of 373 children with a familial history of asthma, an onset of $\mathrm{AD}$ before the age of 2 years was significantly associated with bronchial hyper-reactivity at $7^{57}$. Von Kobyletzki et al found a 3-fold risk of 
asthma if onset of $\mathrm{AD}$ occurred before the age of 12 months, while the risk became nonsignificant after this age $^{58}$. In the Prevention of Allergy among Children in Trondheim (PACT) case-control study, the risk of asthma increased conversely with age of onset of AD: when $\mathrm{AD}$ onset occurred before 3 months, the risk of asthma at the age of 6 years was 4 times higher than for an onset of AD after 3 months $^{59}$. These results could be explained by a higher risk of sensitization in children with early-onset $\mathrm{AD}^{36,60}$. Results from the Children's HEalth and Environmental Research (CHEER) population-based cohort suggest that early-onset AD is associated with a higher risk of asthma if linked with sensitization ${ }^{61}$. Furthermore, in this study, this phenotype of early-onset $\mathrm{AD}$ was also linked with persistent $\mathrm{AD}$ at school-age, suggesting a particular entity grouping early-onset persistent $\mathrm{AD}$, sensitization and asthma.

\section{Severity of $A D$}

In a patient cohort, Gustafsson et al showed that the risk of asthma at school age increased with the severity of $\mathrm{AD}^{46}$. Illi et al demonstrated a 6-fold increase in the risk of school age asthma in children with severe AD in the MAS birth cohort ${ }^{56}$. However, it is important to note that this severe phenotype was infrequent, representing only $1 \%$ of this birth cohort.

An Italian retrospective study, conducted in a cohort of 3-year-old children with AD, found consistent results in terms of $\mathrm{AD}$ severity ${ }^{62}$. These results have since been confirmed in birth cohorts $^{58,63}$.

Recently, a national survey in the United States showed a strong association between severe and persistent $\mathrm{AD}$, and asthma: the prevalence of asthma was $36.9 \%$ in patients with severe AD while it was only $24.3 \%$ for those with mild to moderate AD ( $\mathrm{p}=0.02)$; and the prevalence of severe asthma was also higher in cases of severe $\mathrm{AD}$ compared with mild $\mathrm{AD}$ (36\% versus $5.5 \%$, respectively, $\mathrm{p}<0.0001)$. Once again, the prevalence of severe $\mathrm{AD}$ was low in the overall population, at around $1 \%{ }^{64}$. 
Finally, in a prospective Swedish study of a cohort of 115 children with AD aged under 2 years, AD severity was not only associated with a higher risk of asthma at 10 years $(\mathrm{p}=0.01)$, but also with a higher risk of allergic rhinitis $(\mathrm{p}=0.01)^{65}$.

Male gender

In the Melbourne Atopic Cohort Study (MACS), a birth cohort of 620 children with a parental history of atopy, Lowe et al showed that only boys were prone to the atopic march ${ }^{63}$. According to the authors, one explanation is that $\mathrm{AD}$ is more severe in boys than in girls $(p=0.012)$. The effect persisted after adjustment on sensitization profile and was higher if AD was early-onset and/or severe.

Finally, von Kobyletzki et al in the Dampness in Building and Health (DBH) populationbased study have also shown an excess risk of asthma and allergic rhinitis in boys with AD compared to girls ${ }^{58}$.

$A D$ with early and multiple sensitizations

The results from the ORCA Study describe the natural history of sensitization during the first 6 years of age in children with early-onset moderate to severe AD. In this cohort, food sensitization decreased over time, from 58\% to 34\%, whereas aeroallergen sensitization increased from $17 \%$ to $67 \%$. Initial multiple food sensitization was the most predictive factor for the risk of developing aeroallergen sensitization at 6 years (OR 3.72 [1.68-8.30] $\mathrm{p}<0.001)^{37}$. The cohort was then investigated using an unsupervised statistical hierarchical clustering method. One cluster was characterized by a higher AD severity and frequent food (98.9\%) or aeroallergen (26.2\%) sensitization, often multiple (96.4\% for food allergens). This cluster, called "AD with multiple sensitizations", was the most likely to be associated with allergic asthma at the age of $6(36.1 \%, \mathrm{p}<0.01)^{47}$. In the same way, Lazic et al ${ }^{66}$ recently suggested that allergic phenotypes change little over time, and that one infrequent phenotype 
with sensitization to a wide variety of allergens was much more likely to give rise to asthma during childhood.

Furthermore, the age of onset of these multiple sensitisations seems to affect the subsequent severity of respiratory symptoms, as demonstrated by Belgrave et al in the Manchester Asthma and Allergy population-based study. In this study, children with persistent wheeze, frequent asthma exacerbations, and multiple early atopy have diminished lung function throughout childhood and are at risk of a progressive loss of lung function from age 3 to 11 years. This is especially true for boys ${ }^{67}$.

The AD phenotype characterized by serum IgE levels $\geq 200 \mathrm{kU} / \mathrm{L}$ and food or aeroallergen sensitization is associated with greater disease severity ${ }^{68}$. This form of AD may be considered as the initial step of the atopic march ${ }^{69}$, with severity and early sensitization as major prognostic determinants ${ }^{46,70}$. In this group of patients, immune dysregulation, including higher sensitization levels and increased Th2 cytokine expression in eczematous lesions, may be the underlying pathway leading to the expression of atopic diseases such as allergic asthma $^{71}$. To support this hypothesis, it has been suggested that concomitant early wheeze and $\mathrm{AD}$ does not explain the increased risk of childhood asthma associated with $\mathrm{AD}$, but rather that sensitization is the primary confounding factor in this association ${ }^{63}$.

\section{Genetic factors}

Gene expression seems to differ according to the phenotype, particularly in the genes involved in human keratinocyte and filaggrin expression which is down-regulated in IgErelated $\mathrm{AD}^{68}$. Independently from the well-known role of filaggrin loss-of-function mutations in epithelial dysfunction ${ }^{72}$, other gene mutations in the epidermal differentiation complex could be involved in the severity of $\mathrm{AD}$ and risk of subsequent sensitization to allergens ${ }^{73,74}$. It is also suspected that some polymorphisms of Th2 cytokines interfere with epidermal 
differentiation $^{73}$. In a multi-stage genome-wide association study on infantile eczema followed by childhood asthma including 12 different populations, Marenholz et al identified seven susceptibility loci that could be involved in the atopic march: rs9357733 located in EFHC1 on chromosome 6p12.3 (OR 1.27; p<0.0001), rs993226 between TMTC2 and SLC6A15 on chromosome 12q21.3 (OR 1.58; p<0.0001), FLG (1q21.3), IL4/KIF3A (5q31.1), AP5B1/OVOL1 (11q13.1), C11orf30/LRRC32 (11q13.5) and IKZF3 (17q21) ${ }^{75}$. Familial history is not always considered as a risk factor for the atopic march, although it has been demonstrated to be a risk factor for the transition from early wheezing to asthma ${ }^{58}$. In the ORCA Study, the cluster with the highest rate of parental history of asthma was significantly associated with asthma at the age of 6 years ${ }^{47}$. One hypothesis to explain this result could be a specific genetic susceptibility, involving both inflammation and epithelial barrier pathways.

\section{Role of environmental factors in AD phenotypes}

The role of environmental factors in high risk children should not be minimized.

For instance, many studies have demonstrated a relationship between the content of peanut in house dust and the development of peanut allergy in patients with $\mathrm{AD}^{41,76}$. In highly atopic children recruited from the Consortium of Food Allergy Research Observational Study, environmental peanut exposure was significantly associated with likely peanut allergy (OR 2.34; 95\% CI, 1.31-4.18; $\mathrm{p}<0.01)^{41}$.

Different triggers of AD have been identified such as S. aureus, the herpes simplex virus, stress, and allergens ${ }^{30}$. It is also known that environmental factors play a major role in the development of childhood asthma. However, their relative importance in triggering the atopic march in children with AD has not yet been determined ${ }^{77}$. Studies on pet fur exposure, house dust mites and breastfeeding give contrasting results ${ }^{78,79}$. Recent studies suggest a harmful effect of tobacco smoke exposure, volatile organic compounds, formaldehyde, toluene, nitrogen dioxide and fine particles ${ }^{80}$. These pollutants are suspected to induce a cutaneous 
oxidative stress leading to barrier dysfunction. In utero tobacco smoke exposure seems to be particularly noxious regarding the risk of occurrence of AD for some children ${ }^{81}$, while it could be protective for others ${ }^{82}$. These apparent discrepancies may be due to complex interactions between genetic background and the exposome ${ }^{83}$.

\section{On the borderline between genetics, dysimmunity and AD}

Some orphan syndromes due to heritable mutations in skin barrier components, apart from filaggrin loss-of-function mutations in ichthyosis vulgaris ${ }^{84}$, have been described. These syndromes associate $\mathrm{AD}$ with other various symptoms corresponding to specific entities.

Among these syndromes, the autosomal recessive disorder, Netherton syndrome, is the most well-known. This syndrome is the result of homozygous or compound heterozygous loss-offunction mutations in the SPINK5 gene and is characterized by severe AD associated with a high level of total IgE, and a high frequency of IgE-mediated food allergies ${ }^{85}$.

The recently described severe dermatitis, multiple allergies, and metabolic wasting (SAM) syndrome is caused by mutations in the desmoglein 1 (DSG1) or desmoplakin (DSP) gene ${ }^{86}$. SAM syndrome is rare and only five familial cases have been reported to date. It associates erythrodermia in early-life, developmental delay, severe palmoplantar keratoderma, keratitis, severe $S$ Aureus infections, and multiple FAs. Transcriptomic analysis in these patients has revealed high cytokine expression in keratinocytes, especially TNF, IL-5 and TSLP.

Autosomal dominant hyper-IgE syndrome (also known as STAT3 deficiency), is a primary immunodeficiency disease characterized by severe eczema, recurrent infections, and multiple connective tissue, skeletal and vascular abnormalities ${ }^{87}$. Although not all patients with STAT3 deficiency experience FA, a high rate of eosinophilic esophagitis has been described in these patients $^{88}$.

\section{In practice: Prevention and treatment of AD during childhood}


Recent studies focusing on the prevention of AD in infancy and early childhood have shown an effect of the use of skin barrier creams to prevent $\mathrm{AD}^{89,90}$. Simpson et al ${ }^{89}$ performed a randomized controlled trial including 124 neonates at high risk of AD. Parents in the intervention arm were instructed to apply full-body daily emollient therapy as from 3 weeks of birth. Their results showed a statistically significant $50 \%$ reduction in relative risk on the cumulative incidence of $\mathrm{AD}$ at 6 months with daily use of emollient. Horimukai et $a l^{90}$ in another randomized controlled trial with early moisturizer application conducted in 116 neonates at high familial risk for $\mathrm{AD}$, showed a significant decrease of $40 \%$ of the risk of $\mathrm{AD}$ at 32 weeks of age. These studies suggest that early intervention with emollient therapy from birth is an effective way of preventing $\mathrm{AD}$ and support the concept of skincare respecting the natural barriers from birth. However, data are lacking about a possible effect on food sensitization. Low et al have shown that a twice-daily application of a ceramide-dominant emollient for the first 6 months of life may have an effect on the incidence of sensitization to food at 12 months, but only in a per-protocol analyses (only including infants who received $\geq$ 5 days per week of treatment $)^{91}$. Thus, the effectiveness of this approach in the prevention of sensitization in children remains to be demonstrated.

Taken together, the sum of the pathophysiological facts, observational studies on sensitization risk, and interventional studies, pleads for an active management approach in AD, especially if severe, early-onset, and associated with familial history and early food sensitization. Among the available biotherapies, dupilumab blocks the interleukin-4 receptor thereby inhibiting interleukins 4 and 13. It has been demonstrated to be effective in adults with moderate-to-severe $\mathrm{AD}$ and/or asthma and could be a promising therapy in selected children with severe $\mathrm{AD}^{9}$. However, further studies are needed to show that dupilumab is safe and effective in slowing or preventing the atopic march. 


\section{Conclusion}

$\mathrm{AD}$ should not be seen as a single entity but rather as a condition requiring a translational approach. Clinicians should be aware of specific phenotypes which are linked with subsequent risks of asthma or other associated atopic comorbidities, such as FA. Physicians should be particularly on the lookout for the phenotype comprising severe, early-onset AD, associated with multiple sensitization, because of a poorer respiratory prognosis during life. Association with FA should be carefully investigated in children with difficult-to-treat AD. A dysfunction in filaggrin or Th2-related cytokines or rare genetic syndromes may also explain some severe phenotypes. 


\section{References}

1. Blome C, Radtke MA, Eissing L, Augustin M. Quality of life in patients with atopic dermatitis: disease burden, measurement and treatment benefit. Am J Clin Dermatol 2016; 17: 163-9.

2. Sach TH, McManus E, Mcmonagle C, Levell N. Economic evidence for the prevention and treatment of atopic eczema: a protocol for a systematic review. Syst Rev 2016; 5:90.

3. The International Study of Asthma and Allergies in Childhood (ISAAC) Steering Committee. Worldwide variation in prevalence of symptoms of asthma, allergic rhinoconjunctivitis, and atopic eczema: ISAAC. Lancet 1998; 351: 1225-32.

4. Flohr C, Mann J. New insights into the epidemiology of childhood atopic dermatitis. Allergy 2014; 69: 3-16.

5. Hanifin JM, Rajka G. Diagnostic features of atopic dermatitis. Acta Derm Venereol. 1980;Suppl 92:44-47

6. Williams HC, Burney PG, Hay RJ, Archer CB, Shipley MJ, Hunter JJ, et al. The U.K. Working Party’s Diagnostic Criteria for Atopic Dermatitis. I. Derivation of a minimum set of discriminators for atopic dermatitis. Br J Dermatol 1994;131:383-96.

7. van der Hulst AE, Klip H, Brand PL. Risk of developing asthma in young children with atopic eczema: a systematic review. J Allergy Clin Immunol 2007;120:565-9.

8. Available on: http://skin.cochrane.org/ (26 $6^{\text {th }}$ January, 2018).

9. Boguniewicz M, Alexis AF, Beck LA, Block J, Eichenfield LF, Fonacier L, et al. Expert perspectives on management of moderate-to-severe atopic dermatitis: a current multidisciplinary consensus addressing current and emerging therapies. J Allergy Clin Immunol Pract 2017; 5: 1519-31. 
10. Leung DYM, Boguniewicz M, Howell MD, Nomura I, Hamid QA. New insights into atopic dermatitis. J Clin Invest 2004; 113:651-657.

11. Arikawa J, Ishibashi M, Kawashima M, Takagi Y, Ichikawa Y, Imokawa G. Decreased levels of sphingosine, a natural antimicrobial agent, may be associated with vulnerability of the stratum corneum from patients with atopic dermatitis to colonization by Staphylococcus aureus. J Invest Dermatol 2002; 119:433 - 39.

12. McGrath J, Uitto J. The filaggrin story: novel insights into skin-barrier function and disease. Trends in Molecular Med 2007; 14: 20-26.

13. Ziyab AH, Ewart S, Lockett GA, Zhang H, Arshad H, Holloway JW, et al. Expression of the filaggrin gene in umbilical cord blood predicts eczema risk in infancy: a birth cohort study. Clin Exp Allergy 2017; 47: 1185-1192.

14. Palmer CN, Irvine AD, Terron-Kwiatkowski A, Zhao Y, Liao H, Lee SP, et al. Common loss-of-function variants of the epidermal barrier protein filaggrin are a major predisposing factor for atopic dermatitis. Nat Genet 2006; 38: 441-6.

15. Weidinger S, Illig T, Baurecht H, Irvine AD, Rodriguez E, Diaz-Lacava A, et al. Loss-offunction variations within the filaggrin gene predispose for atopic dermatitis with allergic sensitizations. J Allergy Clin Immunol 2006; 118: 214-9.

16. Ruether A, Stoll M, Schwarz T, Schreiber S, Fölster-Holst R. Filaggrin loss-of-function variant contributes to atopic dermatitis risk in the population of Northern Germany. $\mathrm{Br} \mathrm{J}$ Dermatol 2006; 155: 1093-4.

17. Nomura T, Akiyama M, Sandilands A, Nemoto-Hasebe I, Sakai K, Nagasaki A,et al. Prevalent and rare mutations in the gene encoding filaggrin in Japanese patients with ichthyosis vulgaris and atopic dermatitis. J Invest Dermatol 2009; 129: 1302-5. 
18. Nemoto-Hasebe I, Akiyama M, Nomura T, Sandilands A, McLean WH, Shimizu

H.Clinical severity correlates with impaired barrier in filaggrin-related eczema. J Invest Dermatol 2009; 129: 682-9.

19. Werner Y, Lindberg M. Transepidermal water loss in dry and clinically normal skin in patients with atopic dermatitis. Acta Derm Venereol 1985; 65: 102-5.

20. Gupta J, Grube E, Ericksen MB, Stevenson MD, Lucky AW, Sheth AP, at al. Intrinsically defective skin barrier function in children with atopic dermatitis correlates with disease severity. J Allergy Clin Immunol 2008;121:725-30.

21. Strid J, Hourihane J, Kimber I, Callard R, Strobel S. Disruption of the stratum corneum allows potent epicutaneous immunization with protein antigens resulting in a dominant systemic Th2 response. Eur J Immunol 2004; 34: 2100-9.

22. Kelleher MM, Dunn-Galvin A, Gray C, Murray DM, Kiely M, Kenny L, et al. Skin barrier impairment at birth predicts food allergy at 2 years of age. J Allergy Clin Immunol 2016; 137: 1111-6.

23. Zhu Z, Oh MH, Liu YJ, Zheng T. The role of TSLP in IL-13-induced atopic march. Sc Rep 2011; 1: 1-11.

24. Ong PY, Ohtake T, Brandt C, Strickland I, Boguniewicz M, Ganz T et al. Endigenous antimicrobial peptides and skin infections in atopic dermatitis. N Engl J Med 2002;347:115160.

25. Allakhverdi Z, Comeau M, Jessup HK, Park Yoon BR, Brewer A, Chartier S, et al. Thymic stromal lymphopoietin is released by human epithelial cells in response to microbes, trauma, or inflammation and potently activates mast cells. J Exp Med 2007; 204: 253-58. 26. Demehri S, Morimoto M, Holtzman MJ, Kopan R. Skin-derived TSLP triggers progression from epidermal-barrier defects to asthma. PLoS Biol 2009; 7: e1000067. 
27. Yu J, Hee M, Park JU, Myers AC, Dong C, Zhu Z, et al. Epicutaneous exposure to staphylococcal superantigen enterotoxin B enhances allergic lung inflammation via an IL-17A dependent mechanism. PLoS ONE 2012; 7: e39032.

28. Haapakoski R, Karisola P, Fyhrquist N, Savinko T, Lhetimäki S, Wolff H, et al. Toll-Like Receptor activation during cutaneous allergen sensitization blocks development of asthma through IFN-Gamma-dependent Mechanisms. J Invest Dermatol 2013; 133: 964-72. 29. Noda S, Suarez-Farinas M, Ungar B, Kim SJ, de Guzman Strong C, Xu H, et al. The Asian atopic dermatitis phenotype combines features of atopic dermatitis and psoriasis with increased Th17 polarization. J Allergy Clin Immunol 2015;136:1154-64.

30. Leung DYM. Atopic dermatitis: age and race do matter! J Allergy Clin Immunol 2015;136:1265-7.

31. Ben-Gashir MA, Hay RJ. Reliance on erythema scores may mask severe atopic dermatitis in black children compared with their white counterparts. Br J Dermatol 2002;147:920-925. 32. Vachiramon V, Tey HL, Thompson AE, Yosipovitch G. Atopic dermatitis in African American children: addressing unmet needs of a common disease. Pediatr Dermatol 2012; 29:395-402.

33. Gupta J, Johansson E, Bernstein JA, Chakraborty R, Khurana Hershey GK, et al. Resolving the etiology of atopic disorders by genetic analysis of racial ancestry. J Allergy Clin Immunol 2016 ; 138: 676-699.

34. Tsakok T, Marrs T, Mohsin M, Baron S, du Toit G, Till S, et al. Does atopic dermatitis cause food allergy? A systematic review. J Allergy Clin Immunol 2016;137:1071-8. 35. Hill DJ, Hosking CS. Food allergy and atopic dermatitis in infancy: an epidemiologic study. Pediatr Allergy Immunol 2004;15:421-7. 
36. Lowe AJ, Abramson MJ, Hosking CS, Carlin JB, Bennett CM, Dharmage SC, et al.The temporal sequence of allergic sensitization and onset of infantile eczema. Clin Exp Allergy 2007;37:536-42.

37. Just J, Deslandes-Boutmy E, Amat F, Desseaux K, Nemni A, Bourrat E, et al. Natural history of allergic sensitization in infants with early-onset atopic dermatitis: results from ORCA Study. Pediatr Allergy Immunol 2015: 25: 668-673.

38. Bohme M, Svensson A, Kull I, Nordvall SL, Wahlgren CF. Clinical features of atopic dermatitis at two years of age: a prospective, population-based case control study. Acta Derm Venereol 2001;81:193-7.

39. de Benedictis FM, Franceschini F, Hill D, Naspitz C, Simons FE, Wahn U, et al.The allergic sensitization in infants with atopic eczema from different countries.Allergy 2009;64:295-303.

40. Mortz CG, Lauritsen JM, Andersen KE, Bindslev-Jensen C. Type I sensitization in adolescents: prevalence and association with atopic dermatitis. Acta Derm Venereol 2003;83:194-201.

41. Brough HA, Liu AH, Sicherer S, Makinson K, Douiri A, Brown SJ, et al.Atopic dermatitis increases the effect of exposure to peanut antigen in dust on peanut sensitization and likely peanut allergy. J Allergy Clin Immunol 2015;135:164-70.

42. Du Toit G, Roberts G, Sayre PH, Plaut M, Bahnson HT, Mitchell H,et al. Identifying infants at high risk of peanut allergy: the Learning Early About Peanut Allergy (LEAP) screening study. J Allergy Clin Immunol 2013;131:135-4.

43. Peroni DG, Piacentini GL, Bodini A, Rigotti E, Pigozzi R, Boner AL. Prevalence and risk factors for atopic dermatitis in preschool children. Br J Dermatol 2008;158:539-43. 44. Eller E, Kjaer HF, Host A, Andersen KE, Bindslev-Jensen C. Food allergy and food sensitization in early childhood: results from the DARC cohort. Allergy 2009;64:1023-9. 
45. Loo EXL, Shek LP, Goh A, Teoh OH, Chan YH, Soh SE. Atopic dermatitis in early life: Evidence for at least three phenotypes? Results from the GUSTO Study. Int Arch Allergy Immunol 2015;166:273-79.

46. Gustafsson D, Sjöberg O, Foucard T. Development of allergies and asthma in infants and young children with atopic dermatitis: a prospective follow-up to 7 years of age. Allergy 2000; 55: 240-45.

47. Amat F, Saint-Pierre P, Bourrat E, Nemni A, Couderc R, Boutmy-Deslandes E, Sahraoui F, et al. Early-onset atopic dermatitis in children: which are the phenotypes at risk of asthma? Results from the ORCA Cohort. PLoS ONE 2015; 10: e0131369.

48. Venkataraman D, Soto-Ramirez N, Kurukulaaratchy RJ, Holloway JW, Karmaus W, Ewart SL, et al. Filaggrin loss-of-function mutations are associated with food allergy in childhood and adolescence. J Allergy Clin Immunol 2014;134:876-82.

49. Gray CL, Levin ME, Zar HJ, Potter PC, Khumalo NP, Volkwyn L, et al. Food allergy in South African children with atopic dermatitis. Pediatr Allergy Immunol 2014;25:572-9. 50. Fox AT, Sasieni P, Toit du G, Syed H, Lack G. Household peanut consumption as a risk factor for the development of peanut allergy. J Allergy Clin Immunol 2009; 123:417-23. 51. Fallon PG, Sasaki T, Sandilands A, Campbell LE, Saunders SP, Mangan NE, et al. A homozygous frameshift mutation in the mouse Flg gene facilitates enhanced percutaneous allergen priming. Nat Gen 2009; 41: 602-08.

52. Belgrave DCM, Simpson A, Buchan IE, Custovic A. Atopic dermatitis and respiratory allergy: what is the link? Curr Derm Respir 2015; 4: 221-27.

53. Ashley SE, Tan HTT, Vuillermin P, Dharmage SCm Tang MLK, Koplin J, et al. The skin barrier function gene SPINK5 is associated with challenge-proven IgE-meidated food allergy in infants. Allergy 2017; 72:1356-1364. 
54. Rhodes HL, Sporik R, Thomas P, Holgate ST, Cogswell JJ. Early life risk factors for adult asthma: a birth cohort study of subjects at risk. J Allergy Clin Immunol 2001;108:720-25. 55. Dharmage SC, Lowe AJ, Matheson MC, Burgess JA, Allen KJ, Abramson MJ. Atopic dermatitis and the atopic march revisited. Allergy 2014; 69: 17-27.

56. Illi S, von Mutius E, Lau S, Nickel R, Grüber C, Niggemann B, et al. The natural course of atopic dermatitis from birth to age 7 years and the association with asthma. J Allergy Clin Immunol 2004;113:925-31.

57. Carlsten C, Dimich-Ward H, Ferguson A, Watson W, Rousseau R, Dybuncio A, et al. Atopic dermatitis in a high-risk cohort: natural history, associated allergic outcomes, and risk factors. Ann Allergy Asthma Immunol 2013;110: 24-28.

58. von Kobyletzki LB, Bornehag CG, Hasselgren M, Larsson M, Lindström CB, Svensson A. Eczema in early childhood is strongly associated with the development of asthma and rhinitis in a prospective cohort. BMC Dermatol 2012; 12:11.

59. Saunes M, Oien T, Dotterud C, Romundstad PR, Storro O, Holmen TL. Early eczema and the risk of childhood asthma:a prospective, population-based study. BMC Pediatrics 2012; 12:168.

60. Ricci G, Dondi A, Neri I, Ricci L, Patrizi A, Pession A. Atopic dermatitis phenotypes in childhood. Ital J Ped 2014; 40:46.

61. Lee E, Lee SH, Kwon JW, Kim YH, Cho HJ, Yang SI, et al. Atopic dermatitis phenotype with early onset and high serum IL-13 is linked to the new development of bronchial hyperresponsiveness in school children. Allergy 2016; 71: 692-700.

62. Ricci G, Patrizi A, Baldi E, Menna G, Tabanelli M, et al. Long-term follow-up of atopic dermatitis: Retrospective analysis of related risk factors and association with concomitant allergic diseases. J Am Acad Dermatol 2006;55:765-71. 
63. Lowe AJ, Carlin JB, Bennett CM, Hosking CS, Abramson MJ, Hill DJ, et al. Do the boys do the atopic march while girls dawdle? J Allergy Clin Immunol 2008;121:1190-95.

64. Silverberg JI, Simpson EL. Association between severe eczema in children and multiple comorbid conditions and increased healthcare utilization. Pediatr Allergy Immunol 2013; 24: 476-86.

65. Eckbäck M, Tedner M, Devenney I, Oldaeus G, Norman G, Strömberg L, et al. Severe eczema in infancy can predict asthma development. A prospective study to the age of 10 years.PLoS One 2014; 9: e99609.

66. Lazic N, Roberts G, Custovic A,Belgrave D, Bishop CM, Winn J, et al. Multiple atopy phenotypes and their associations with asthma: similar findings from two birth cohorts. Allergy 2013: 68:764-70.

67. Belgrave DCM, Buchan I, Bishop C, Lowe L, Simpson A, Custovic A. Trajectories of lung function during childhood. Am J Respir Crit Care Med 2014; 189: 1101-1109.

68. Suarez-Farinas M, Dhingra N, Gittler J, Shemer A, Cardinale I, de Guzman Strong C, Guttman-Yassky E. Intrinsic atopic dermatitis shows similar Th2 and higher Th17 immune activation compared with extrinsic atopic dermatitis. J Allergy Clin Immunol 2013; 132: 36170.

69. Bieber T, Cork M, Reitamo S. Atopic dermatitis: a candidate for disease-modifying strategy. Allergy 2012; 67: 969-75.

70. Nissen SP, Kjaer HF, Host A, Nielsen J, Halken S. The natural course of sensitization and allergic diseases from childhood to adulthood. Pediatr Allergy Immunol 2013; 24: 549-55.

71. Brown S, Reynolds NJ. Atopic and non-atopic eczema. Br Med J 2006; 332: 584-88.

72. Samuelov L, Sprecher E. Peeling off the genetics of atopic dermatitis-like congenital disorders. J Allergy Clin Immunol 2014;134:808-15. 
73. Thyssen JP, Kezic S. Causes of epidermal filaggrin reduction and their role in the pathogenesis of atopic dermatitis. J Allergy Clin Immunol 2014;134:792-9.

74.Elias PM, Wakefield JS. Mechanisms of abnormal lamellar body secretion and the dysfunctional skin barrier in patients with atopic dermatitis. J Allergy Clin Immunol 2014;134:781-91.

75. Marenholz I, Esparza-Gordillo J, Rüschendorf F, Bauerfeind A, Strachan DP, Spycher BD, et al. Meta-analysis identifies seven susceptibility loci involved in the atopic march. Nat Commun 2015; 6:8804.

76. Brough HA, Simpson A, Makinson K, Hankinson J, Brown S, Douiri A, et al. Peanut allergy: effect of environmental peanut exposure in children with filaggrin loss-of-function mutations. J Allergy Clin Immunol 2014;134:867-75.

77. Wegienka G, Zoratti E, Cole Johnson C. The role of the early-life environment in the development of allergic disease. Immunol Allergy Clin North Am 2015; 35: 1-17.

78. Maas T, Kaper J, Sheikh A, Knottnerus JA, Wesseling G, Dompeling E, et al. Mono and multifaceted inhalant and/or food allergen reduction interventions for preventing asthma in children at high risk of developing asthma (Review). Evid Based Child Health 2010; 5: 1385450.

79. Duncan JM, Sears MR. Breastfeeding and allergies: time for a change in paradigm? Curr Op Allergy Clin Immunol 2008, 8:398-405.

80. Ahn K. The role of air pollutants in atopic dermatitis. J Allergy Clin Immunol 2014;134:993-99.

81. Yi O, Kwon HJ, Kim H, Ha M, Hong SJ, Hong YC, et al. Effect of environmental tobacco smoke on atopic dermatitis among children in Korea. Env Res 2012; 113: 40-45. 
82. Taylor-Robinson DC, Williams H, Pearce A, Law C, Hope S. Do early-life exposures explain why more advantaged children get eczema? Findings from the U.K. Millennium Cohort Study. Br J Dermatol 2016; 174: 569-78.

83. Custovic A. To what extent is allergen exposure a risk factor for the development of allergic disease? Clin Exp Allergy 2015; 45: 54-62.

84. Proksch E, Fölster-Holst R, Braütigam M, Sepehrmanesh M, Peiffer S, Jensen JM. Role of the epidermal barrier in atopic dermatitis. J Germ Soc Dermatol 2009; 7: 899-910.

85. Chavanas S, Bodemer C, Rochat A, Hamel-Teillac D, Ali M, Irvine AD, et al. Mutations in SPINK5, encoding a serine protease inhibitor, cause Netherton syndrome. Nat Genet 2000;25:141-2

86. Samuelov L, Sarig O, Harmon RM, Rapaport D, Ishida-Yamamoto A, Isakov O, et al. Desmoglein 1 deficiency results in severe dermatitis, multiple allergies and metabolic wasting. Nat Gen 2013; 45: 1244-8.

87. Grimbacher B, et al. Hyper-IgE syndrome with recurrent infections - an autosomal dominant multisystem disorder. N Engl J Med 1999; 340: 692-702.

88. Arora M, Bagi P, Strongin A, Heimall J, Zhao X, Lawrence MG, et al. Gastrointestinal manifestations of STAT3-deficient hyper-IgE syndrome. J Clin Immunol 2017 (e-pub ahead of print).

89. Simpson EL, Chalmers JR, Hanifin JM, Thomas KS, Cork MJ, McLean WH, et al.Emollient enhancement of the skin barrier from birth offers effective atopic dermatitis prevention. J Allergy Clin Immunol 2014;134:818-23.

90. Horimukai K, Morita K, Narita M, Kondo M, Kitazawa H, Nozaki M, et al. Application of moisturizer to neonates prevents development of atopic dermatitis.J Allergy Clin Immunol 2014;134:824-30. 
91. Lowe AJ, Su JC, Allen KJ, Abramson MJ, Cranswick N, Robertson CF, et al. A randomized trial of a barrier lipid replacement strategy for the prevention of atopic dermatitis and allergic sensitization: the PEBBLES pilot study. Br J Dermatol 2017; e-pub ahead of print

Table 1 - Terms used to identify studies focused on AD, adapted from Cochrane Skin Group guidelines

\begin{tabular}{lll}
\hline Definite AD & $\begin{array}{l}\text { Possible AD (AD retained } \\
\text { if additional features } \\
\text { obtained in the original } \\
\text { paper as a good clinical } \\
\text { description) }\end{array}$ & Not atopic eczema \\
\hline Atopic eczema & Childhood eczema & Seborrheic dermatitis/eczema \\
Atopic dermatitis & Infantile eczema & Contact dermatitis/eczema \\
& Eczema (unspecified) & Occupational \\
Dyshidrotic eczema & dermatitis/eczema \\
Nummular dermatitis & Hand dermatitis/eczema \\
& Pityriasis alba & Allergic contact \\
& & dermatitis/eczema \\
& & Irritant contact \\
& dermatitis/eczema \\
\hline
\end{tabular}


Table 2 - Main definitions for atopic dermatitis, atopic eczema and eczema

\begin{tabular}{ll}
\hline Authors, date & Definition \\
\hline Hanifin \& & Atopic dermatitis (syn. atopic eczema), defined by at least three of the following \\
Rajka, 1980 & features: \\
& - Pruritus, \\
& - Lichenification, \\
& - Chronically relapsing course, \\
& - Personal of familial history of atopy \\
& Plus 3 or more minor features: \\
& - Xerosis \\
& - Ichtyosis/palmar hyperlinearity \\
& -Immediate skin test reactivity \\
& - Elevated serum IgE \\
& - Early age of onset \\
& - Tendency toward cutaneous infections/impaired cell-mediated immunity \\
& - Tendency toward non-specific hand or foot dermatitis \\
& - Nipple eczema \\
& - Cheilitis \\
& -Recurrent conjunctivitis \\
& - Dennie-Morgan infraorbital fold \\
& - Keratocornus \\
& - Anterior subscapular cataracts \\
- Orbital darkening \\
- Facial pallor/facial erythema \\
- Pytiriasis alba \\
- Anterior neck folds \\
- Itch when sweating \\
- Intolerance to wool and lipid solvents \\
- Perifollicular accentuation \\
- Food intolerance \\
- Course influenced by environmental/emotional factors \\
- White dermographism/ delayed blanch \\
Atopic dermatitis, defined by: \\
Evidence of itchy skin (or parental report of scratching or rubbing) plus three or \\
more of the following: \\
- History of involvement of the skin creases (e.g. fronts of elbows, backs of knees, \\
fronts of ankles, and areas around the neck or eyes) \\
\hline Williams et al \\
\end{tabular}


- History of asthma or hay fever (or history of atopic disease in a first-degree relative if the child is under four years of age)

- History of generally dry skin in the past year

- Onset in a child under 2 years of age (criterion not used if the child is under four years of age)

- Visible flexural dermatitis (including dermatitis affecting the cheeks or forehead and outer aspects of limbs in children under four years)

ISAAC Study Current atopic eczema, defined if answered "Yes" to the questions:

Group, $1998 \quad$ - "Have you ever had an itchy rash which was coming and going for at least 6 months? If yes:

- "Have you had this itchy rash at any time in the last 12 months?” If yes:

- "Has this itchy rash at any time affected any of the following places: the folds of the elbows, behind the knees, in front of the ankles, under the buttocks, or around the neck, ears, or eyes?"

UKWP: United Kingdom Working Party; ISAAC: International Study of Asthma and Allergies in Childhood

Table 3 - Role of filaggrin variants in AD expression: summary of main results

\begin{tabular}{|c|c|c|c|c|c|c|}
\hline Authors, date & $\begin{array}{l}\text { Terms } \\
\text { and } \\
\text { definition } \\
\text { s used* }\end{array}$ & $\begin{array}{l}\text { Type of } \\
\text { study }\end{array}$ & Population & Aim & Main results & $\begin{array}{l}\text { Conclusion } \\
\text { s }\end{array}$ \\
\hline $\begin{array}{l}\text { Palmer et al, } \\
2006\end{array}$ & $\begin{array}{l}\text { AD, } \\
\text { eczema } \\
(\mathrm{UKWP})\end{array}$ & $\begin{array}{l}\text { Case- } \\
\text { control } \\
\text { with } \\
\text { replication } \\
\text { in } 2 \\
\text { population } \\
\text {-based } \\
\text { cohorts }\end{array}$ & $\begin{array}{l}\text { Children } \\
189 \\
\text { controls, } 52 \\
\text { cases with } \\
\text { AD } \\
21 \text { cases } \\
\text { with AD + } \\
\text { asthma } \\
\text { Replication } \\
: 1008 \text { and } \\
604 \\
\text { subjects }\end{array}$ & $\begin{array}{l}\text { To assess the } \\
\text { role of FLG } \\
\text { R501X and } \\
\text { 2282del4 } \\
\text { variants in } \\
\text { predispositio } \\
\text { n for AD in } \\
\text { Irish, Scottish } \\
\text { and Danish } \\
\text { populations }\end{array}$ & $\begin{array}{l}\text { Risk of AD for } \\
\text { carriers of at } \\
\text { least one allele: } \\
\text { - in Irish } \\
\text { subjects: } \\
\text { OR13.4 [6.2- } \\
\text { 27.5] } \\
\text { - in Scottish } \\
\text { subjects: } \\
\text { OR 1.8 [1.3-2.5] } \\
\text { - in Danish } \\
\text { subjects: } \\
\text { HR 2.8 [1.7 - } \\
\text { 4.5] }\end{array}$ & $\begin{array}{l}\text { Key } \\
\text { role of } \\
\text { impaired skin } \\
\text { barrier } \\
\text { function in the } \\
\text { development } \\
\text { of } \\
\text { atopic disease }\end{array}$ \\
\hline $\begin{array}{l}\text { Weidinger et } \\
\text { al, } 2006\end{array}$ & $\begin{array}{l}\text { AD } \\
\text { (UKWP) }\end{array}$ & $\begin{array}{l}\text { Family- } \\
\text { based }\end{array}$ & $\begin{array}{l}476 \\
\text { families }\end{array}$ & $\begin{array}{l}\text { To assess the } \\
\text { role of } \\
\text { R510X and } \\
\text { 2282del } 4 \\
\text { variants in } \\
\text { predispositio } \\
n \text { for AD }\end{array}$ & $\begin{array}{l}\text { Risk of AD while } \\
\text { carrying } \\
\text { - 2282del4 } \\
\text { variant: } \\
\text { OR 2.5[1.4-4.3] } \\
\text { - R501X variant: } \\
\text { OR 4.1[2.2-7.9] } \\
\text {-combined } \\
\text { genotype: } \\
\text { OR 3.3[2.1-5.4] } \\
\text { Particular } \\
\text { association with } \\
\text { “extrinsic” AD, } \\
\text { characterized by } \\
\text { high total serum } \\
\text { IgE levels and } \\
\text { concomitant } \\
\text { allergic } \\
\text { sensitizations }\end{array}$ & $\begin{array}{l}\text { FLG is the } \\
\text { first } \\
\text { really strong } \\
\text { genetic factor } \\
\text { identified in a } \\
\text { common } \\
\text { complex } \\
\text { disease } \\
\text { Crucial role } \\
\text { of the skin } \\
\text { barrier in } \\
\text { preventing } \\
\text { allergic } \\
\text { sensitization }\end{array}$ \\
\hline $\begin{array}{l}\text { Ruether et al, } \\
2006\end{array}$ & $\begin{array}{l}\text { AD } \\
\text { (Hanifin \& } \\
\text { Rajka) }\end{array}$ & $\begin{array}{l}\text { Case- } \\
\text { control and } \\
\text { family- }\end{array}$ & $\begin{array}{l}\text { Children } \\
272 \text { cases } \\
276\end{array}$ & $\begin{array}{l}\text { To explore } \\
\text { further the } \\
\text { relevance of }\end{array}$ & $\begin{array}{l}\text { Risk of AD while } \\
\text { carrying R501X } \\
\text { variant: }\end{array}$ & $\begin{array}{l}\text { FLG variants } \\
\text { are specific to } \\
\text { the epidermal }\end{array}$ \\
\hline
\end{tabular}




\begin{tabular}{|c|c|c|c|c|c|c|}
\hline & & based & $\begin{array}{l}\text { controls } \\
338 \\
\text { families }\end{array}$ & $\begin{array}{l}\text { the variants } \\
\text { in Northern } \\
\text { Germany }\end{array}$ & $\begin{array}{l}\text { OR 3.39 [1.75- } \\
6.58] \\
\text { AD risk while } \\
\text { carrying } \\
\text { 2282del4 variant } \\
=\text { OR } 7.1 \text { [3.41- } \\
\text { 14.78] }\end{array}$ & $\begin{array}{l}\text { barrier, and are } \\
\text { major } \\
\text { predisposing } \\
\text { factors for AD } \\
\text { in Western } \\
\text { European } \\
\text { populations }\end{array}$ \\
\hline $\begin{array}{l}\text { Nomura et al, } \\
2009\end{array}$ & $\begin{array}{l}\text { AD (not } \\
\text { specified) }\end{array}$ & $\begin{array}{l}\text { Case- } \\
\text { control }\end{array}$ & $\begin{array}{l}\text { Children } \\
\text { and adults } \\
118 \text { cases } \\
134 \\
\text { controls }\end{array}$ & $\begin{array}{l}\text { To assess the } \\
\text { link between } \\
\text { FLG } \\
\text { mutations } \\
\text { and AD in a } \\
\text { Japanese } \\
\text { population }\end{array}$ & $\begin{array}{l}\text { Seven variants } \\
\text { described:R501X } \\
\text {, 3321delA, } \\
\text { S1695X, } \\
\text { Q1701X, } \\
\text { S2554X, } \\
\text { S2889X, S3296X } \\
\text { Risk of AD if } \\
\text { combined } \\
\text { genotype: OR } \\
\text { 6.8[2.5-18.5] }\end{array}$ & $\begin{array}{l}\text { FLG mutations } \\
\text { are population- } \\
\text { specific }\end{array}$ \\
\hline $\begin{array}{l}\text { Nemoto- } \\
\text { Hasebe et al, } \\
2009\end{array}$ & $\begin{array}{l}\text { AD } \\
\text { (Hanifin \& } \\
\text { Rajka) }\end{array}$ & $\begin{array}{l}\text { Case- } \\
\text { control }\end{array}$ & $\begin{array}{l}\text { Adults } \\
24 \text { cases } \\
12 \text { controls }\end{array}$ & $\begin{array}{l}\text { Main } \\
\text { hypothesis: } \\
\text { skin barrier } \\
\text { defects } \\
\text { caused by } \\
\text { FLG } \\
\text { deficiency is } \\
\text { a } \\
\text { primary } \\
\text { abnormality } \\
\text { leading to the } \\
\text { AD } \\
\text { symptoms }\end{array}$ & $\begin{array}{l}\text { In filaggrin- } \\
\text { related AD, } \\
\text { objective score of } \\
\text { atopic dermatitis } \\
\text { correlated with } \\
\text { - TEWL r }=0.81 \text {, } \\
\text { p }<0.005 \\
\text { - SC hydration: } \\
\text { r=0.65,p }<0.05 \\
\text { - SC thickness: } \\
r=0.59, p<0.05\end{array}$ & $\begin{array}{l}\text { Skin barrier } \\
\text { defects due to } \\
\text { FLG mutations } \\
\text { may play a } \\
\text { crucial role in } \\
\text { the } \\
\text { pathogenesis } \\
\text { of AD }\end{array}$ \\
\hline $\begin{array}{l}\text { Venkatarama } \\
\text { n et al, } 2014\end{array}$ & $\begin{array}{l}\text { AD } \\
\text { (Hanifin \& } \\
\text { Rajka) }\end{array}$ & $\begin{array}{l}\text { Population } \\
\text {-based } \\
\text { birth } \\
\text { cohort }\end{array}$ & $\begin{array}{l}1313 \\
\text { children at } \\
\text { the end of } \\
\text { the follow- } \\
\text { up }\end{array}$ & $\begin{array}{l}\text { To explore } \\
\text { the } \\
\text { longitudinal } \\
\text { relationship } \\
\text { between } 3 \\
\text { common } \\
\text { FLG-LOF } \\
\text { variants and } \\
\text { FA }\end{array}$ & $\begin{array}{l}\text { Effect of FLG- } \\
\text { LOF variants on } \\
\text { the risk of FA: } \\
\text { - at } 10 \text { years: OR } \\
31.46 \text { [2.86->100 } \\
\text { - at } 18 \text { years: } \\
4.25 \text { [1.55-11.61] } \\
\text { Indirect effect of } \\
\text { FLG variants on } \\
\text { FA at all ages } \\
\text { through } \\
\text { eczema and FS }\end{array}$ & $\begin{array}{l}\text { FLG-LOF } \\
\text { mutations are } \\
\text { associated } \\
\text { with FA in } \\
\text { older children } \\
\text { through } \\
\text { eczema and FS } \\
\text { during early } \\
\text { childhood. } \\
\text { Biologically } \\
\text { plausible } \\
\text { pathway } \\
\text { suggesting that } \\
\text { skin barrier } \\
\text { function is } \\
\text { important in } \\
\text { the } \\
\text { development } \\
\text { and } \\
\text { persistence of } \\
\text { FA. }\end{array}$ \\
\hline $\begin{array}{l}\text { Ziyab et al, } \\
2017\end{array}$ & $\begin{array}{l}\text { Eczema } \\
\text { (Hanifin \& } \\
\text { Rajka) }\end{array}$ & $\begin{array}{l}\text { Population } \\
\text {-based } \\
\text { birth } \\
\text { cohort }\end{array}$ & 94 children & $\begin{array}{l}\text { To assess } \\
\text { whether FLG } \\
\text { expression in } \\
\text { UCB } \\
\text { associates } \\
\text { with and } \\
\text { predicts the } \\
\text { development }\end{array}$ & $\begin{array}{l}\text { RR of eczema } \\
\text { during the first } \\
\text { year of life if } \\
\text { increased level of } \\
\text { FLG } \\
\text { expression:0.60 } \\
\text { [0.38-0.95] } \\
\text { RR of eczema }\end{array}$ & $\begin{array}{l}\text { FLG } \\
\text { expression in } \\
\text { UCB is } \\
\text { associated } \\
\text { with eczema } \\
\text { development } \\
\text { in infancy }\end{array}$ \\
\hline
\end{tabular}




\begin{tabular}{ll}
\hline of eczema in & during the first \\
infancy & year of life if \\
& increased level of \\
& FLG antisense \\
& transcripts : \\
& $2.02[1.10-3.72]$ \\
\hline
\end{tabular}

AD: atopic dermatitis; UKWP: United Working Party Criteria; FLG: filaggrin; OR: odds ratio, 95\% confidence interval expressed [-]; HR: hazard ratio; TEWL: transepidermal waterloss; SC: subcutaneous; LOF: loss-of-function; RR: relative risk; UCB: umbilical cordon blood

*Terms between brackets specify the criteria used to define AD

Table 4 -Link between AD, food sensitization and food allergy: summary of main results

\begin{tabular}{|c|c|c|c|c|c|c|}
\hline $\begin{array}{l}\text { Authors, } \\
\text { date }\end{array}$ & $\begin{array}{l}\text { Terms and } \\
\text { definitions } \\
\text { used* }\end{array}$ & $\begin{array}{l}\text { Type of } \\
\text { study }\end{array}$ & Population & Aim & Main results & Conclusions \\
\hline $\begin{array}{l}\text { Carlsten } \\
\text { et al, } \\
2013\end{array}$ & $\begin{array}{l}\text { AD (presence of } \\
\text { a pruritic rash on } \\
\text { the face or } \\
\text { extensor surface } \\
\text { of the arms or } \\
\text { legs and flexural } \\
\text { lichenification at } \\
\text { the time of } \\
\text { examination by } \\
\text { the allergist } \\
\text { investigators) }\end{array}$ & $\begin{array}{l}\text { High-risk } \\
\text { cohort }\end{array}$ & $\begin{array}{l}373 \\
\text { children }\end{array}$ & $\begin{array}{l}\text { To evaluate } \\
\text { the natural } \\
\text { history of AD } \\
\text { and its } \\
\text { association } \\
\text { with other } \\
\text { allergic } \\
\text { outcomes }\end{array}$ & $\begin{array}{l}\text { Risk of FS at } 2 \\
\text { years if } \\
\text { associated AD: } \\
\text { OR 2.52 [1.11- } \\
5.74] \text { (if non } \\
\text { persistent) } \\
\text { OR 5.92 [2.23- } \\
\text { 15.7] (if } \\
\text { persistent) } \\
\text { Risk of FA at } 7 \\
\text { years if early- } \\
\text { onset persistent } \\
\text { AD: } \\
\text { OR13.4[2.94- } \\
61.4] \\
\text { Non significant } \\
\text { risk of FS or } \\
\text { FA if late- } \\
\text { onset }\end{array}$ & $\begin{array}{l}\text { Only early- } \\
\text { onset, } \\
\text { persistent AD } \\
\text { is } \\
\text { associated with } \\
\text { atopic } \\
\text { sensitization }\end{array}$ \\
\hline $\begin{array}{l}\text { Du Toit } \\
\text { et al, } \\
2013\end{array}$ & $\begin{array}{l}\text { AD } \\
\text { (Hanifin \& } \\
\text { Rajka) }\end{array}$ & $\begin{array}{l}\text { High-risk } \\
\text { cohort }\end{array}$ & $\begin{array}{l}834 \\
\text { children }\end{array}$ & $\begin{array}{l}\text { To } \\
\text { characterize a } \\
\text { population } \\
\text { screened for } \\
\text { the risk of } \\
\text { PA. }\end{array}$ & $\begin{array}{l}\text { PS was } \\
\text { associated with } \\
\text { severe eczema: } \\
\text { OR 2.47 [1.14- } \\
5.34 \text { ] }\end{array}$ & $\begin{array}{l}\text { Severe eczema } \\
\text { useful criterium } \\
\text { for identifying } \\
\text { PA high-risk } \\
\text { infants }\end{array}$ \\
\hline $\begin{array}{l}\text { Gray et } \\
\text { al, } 2014\end{array}$ & AD (UKWP) & $\begin{array}{l}\text { Patient } \\
\text { cohort }\end{array}$ & $\begin{array}{l}100 \\
\text { children }\end{array}$ & $\begin{array}{l}\text { To determine } \\
\text { the } \\
\text { prevalence } \\
\text { of, and risk } \\
\text { factors for, } \\
\text { IgE-mediated } \\
\text { FA in South } \\
\text { African } \\
\text { children with } \\
\text { AD }\end{array}$ & $\begin{array}{l}66 \% \text { of } \\
\text { associated FS } \\
40 \% \text { of } \\
\text { associated FA: } \\
\text { egg } 25 \% \text {, PS } \\
24 \% \\
\text { Comparable } \\
\text { FS rates } \\
\text { between } \\
\text { Blacks and } \\
\text { mixed race } \\
\text { patients, but }\end{array}$ & $\begin{array}{l}\text { Unexpectedly } \\
\text { high prevalence } \\
\text { of FA in South } \\
\text { African } \\
\text { children with } \\
\text { AD } \\
\text { Ethnic } \\
\text { background } \\
\text { differences }\end{array}$ \\
\hline
\end{tabular}




\begin{tabular}{|c|c|c|c|c|c|c|}
\hline & & & & & $\begin{array}{l}\text { lower PA rates } \\
\text { in Blacks } \\
\text { Risk factors for } \\
\text { FA: early- } \\
\text { onset AD ( }<6 \\
\text { months), } \\
\text { severe } \\
\text { eczema, and } \\
\text { age }<2 \text { years }\end{array}$ & \\
\hline $\begin{array}{l}\text { Just et } \\
\text { al, } 2015\end{array}$ & $\begin{array}{l}\text { AD (UKWP and } \\
\text { ISAAC) }\end{array}$ & $\begin{array}{l}\text { Patient } \\
\text { cohort }\end{array}$ & $\begin{array}{l}229 \\
\text { children }\end{array}$ & $\begin{array}{l}\text { To describe } \\
\text { the natural } \\
\text { history of } \\
\text { sensitization } \\
\text { in a cohort of } \\
\text { children with } \\
\text { early-onset } \\
\text { AD }\end{array}$ & $\begin{array}{l}\text { FS decreased } \\
\text { from } 58 \% \text { to } \\
34 \% \text { from } 1 \text { to } \\
6 \text { years } \\
\text { Risk of } \\
\text { developing } \\
\text { sensitization to } \\
\text { inhaled } \\
\text { allergens if } \\
\text { initial multiple } \\
\text { FS: } \\
\text { OR 3.72 [1.68- } \\
\text { 8.30] }\end{array}$ & $\begin{array}{l}\text { Multiple FS } \\
\text { conveys a } \\
\text { higher risk of } \\
\text { sensitization to } \\
\text { inhaled } \\
\text { allergens than } \\
\text { single FS }\end{array}$ \\
\hline $\begin{array}{l}\text { Brough } \\
\text { et al, } \\
2015\end{array}$ & $\begin{array}{l}\text { AD (Hanifin \& } \\
\text { Rajka) }\end{array}$ & $\begin{array}{l}\text { Patient } \\
\text { cohort }\end{array}$ & $\begin{array}{l}512 \\
\text { children }\end{array}$ & $\begin{array}{l}\text { To assess } \\
\text { whether } \\
\text { EPE is a risk } \\
\text { for PS and } \\
\text { PA }\end{array}$ & $\begin{array}{l}\text { Effect of EPE } \\
\text { on PS: } \\
\text { - if history of } \\
\text { AD: } \\
\text { OR } 1.97 \text { [1.26- } \\
3.09] \\
\text { - if history of } \\
\text { severe AD OR } \\
2.41 \text { [1.30- } \\
4.47] \\
\text { Effect of EPE } \\
\text { on PA if } \\
\text { history of AD: } \\
\text { OR 2.34 [1.31- } \\
4.18]\end{array}$ & $\begin{array}{l}\text { Exposure to } \\
\text { peanut antigen } \\
\text { in dust through } \\
\text { an } \\
\text { impaired skin } \\
\text { barrier in atopic } \\
\text { inflamed skin is } \\
\text { a plausible } \\
\text { route for PS } \\
\text { and PA }\end{array}$ \\
\hline $\begin{array}{l}\text { Kelleher } \\
\text { et al, } \\
2016\end{array}$ & AD (UKWP) & $\begin{array}{l}\text { Population- } \\
\text { based birth } \\
\text { cohort }\end{array}$ & $\begin{array}{l}1903 \\
\text { children }\end{array}$ & $\begin{array}{l}\text { To examine } \\
\text { whether early } \\
\text { skin barrier } \\
\text { disruption, } \\
\text { based on } \\
\text { TEWL } \\
\text { assessment, is } \\
\text { associated } \\
\text { with } \\
\text { increased } \\
\text { rates of FS or } \\
\text { FA at } 2 \text { years } \\
\text { of age. }\end{array}$ & $\begin{array}{l}\text { FS } 6.27 \% \\
\text { FA } 4.45 \% \\
\text { Egg: most } \\
\text { prevalent } \\
\text { allergen } \\
\text { (2.94\%), then } \\
\text { peanut } \\
\text { (1.75\%), and } \\
\text { cow’s milk } \\
\text { (0.74\%) } \\
\text { Day } 2 \\
\text { TEWL>9 g } \\
\text { water/m²/h } \\
\text { significant } \\
\text { predictor of FA } \\
\text { at age } 2 \text { years: } \\
\text { OR } 4.1 \text { [1.5- } \\
\text { 4.8] }\end{array}$ & $\begin{array}{l}\text { Neonatal skin } \\
\text { barrier } \\
\text { dysfunction } \\
\text { predicts FA at } \\
2 \text { years of age, } \\
\text { supporting the } \\
\text { concept of } \\
\text { transcutaneous } \\
\text { allergen } \\
\text { sensitization }\end{array}$ \\
\hline $\begin{array}{l}\text { Tsakok } \\
\text { et al, } \\
2016\end{array}$ & $\begin{array}{l}\text { AD, atopic } \\
\text { eczema, eczema } \\
\text { (exclusion of } \\
\text { sensitization- } \\
\text { based AD) }\end{array}$ & $\begin{array}{l}\text { Systematic } \\
\text { review }\end{array}$ & $\begin{array}{l}\text { Children } \\
11 \\
\text { population- } \\
\text { based } \\
\text { studies }\end{array}$ & $\begin{array}{l}\text { To review the } \\
\text { association } \\
\text { between AD } \\
\text { and } \\
\text { FA, the effect }\end{array}$ & $\begin{array}{l}\text { Likelihood of } \\
\text { FS in patients } \\
\text { with AD } \\
\text { at } 3 \text { months of } \\
\text { age = OR }\end{array}$ & $\begin{array}{l}\text { Strong and } \\
\text { dose-dependent } \\
\text { association } \\
\text { between AD, } \\
\text { food }\end{array}$ \\
\hline
\end{tabular}




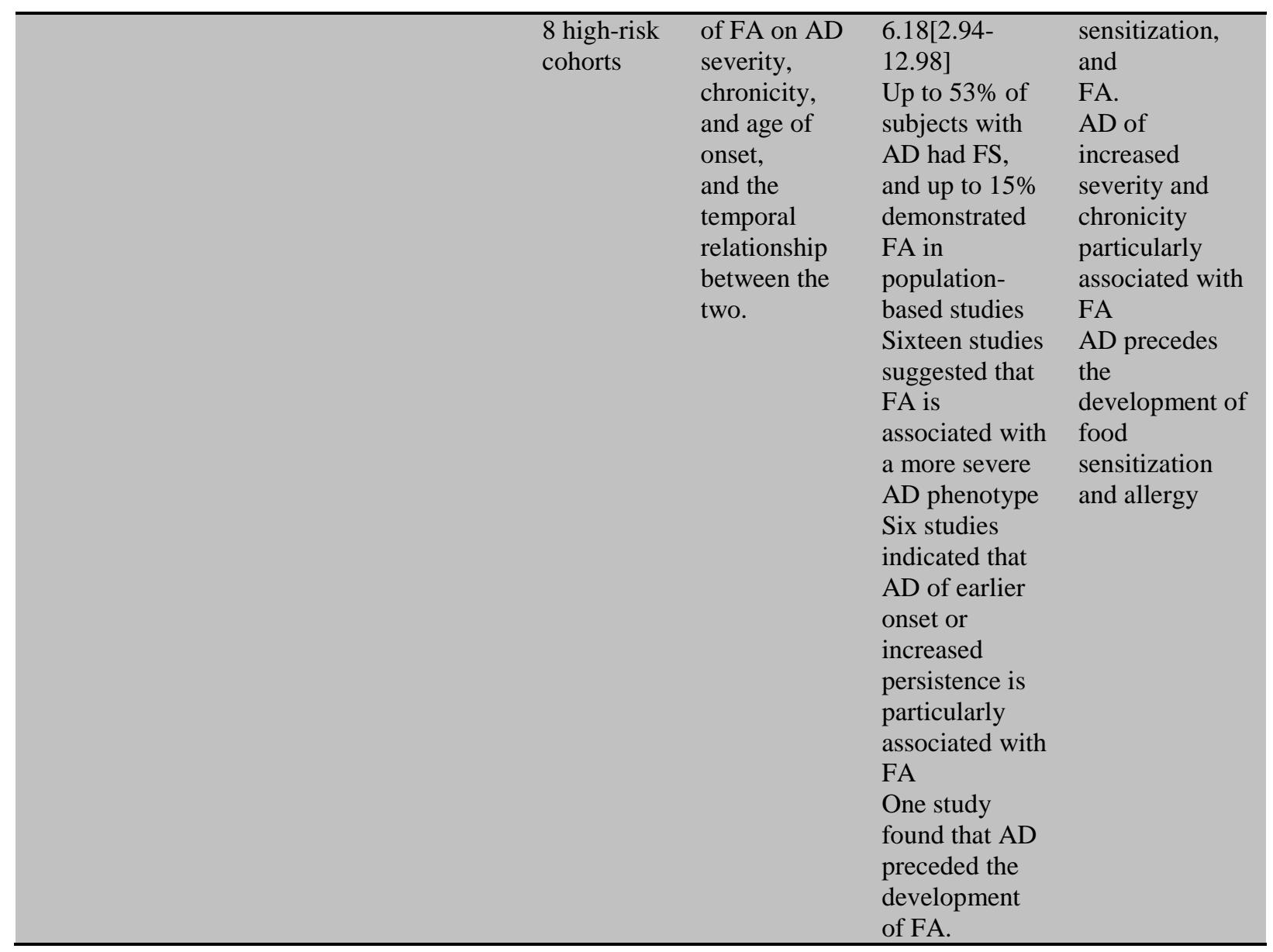

AD: atopic dermatitis; FS: food sensitization; FA: food allergy; PS: peanut sensitization; OR: odds ratio, 95\% confidence interval expressed [-]; PA: peanut allergy; UKWP: United Working Party Criteria; ISAAC: International Study of Asthma and Allergies in Childhood; TEWL: transepidermal water-loss; EPE: environmental peanut exposure.

*Terms between brackets specify the criteria used to define AD 
Table 5 - Link between AD and asthma: summary of main results

\begin{tabular}{|c|c|c|c|c|c|c|}
\hline $\begin{array}{l}\text { Authors, } \\
\text { date }\end{array}$ & $\begin{array}{l}\text { Terms and } \\
\text { definitions } \\
\text { used* }\end{array}$ & $\begin{array}{l}\text { Type of } \\
\text { study }\end{array}$ & Population & Aim & Main results & Conclusions \\
\hline $\begin{array}{l}\text { Illi et al, } \\
2004\end{array}$ & $\begin{array}{l}\text { AD (at least } \\
\text { one of the } \\
\text { following } 3 \\
\text { criteria } \\
\text { applied at any } \\
\text { follow-up } \\
\text { visit in the } \\
\text { first } 2 \text { years of } \\
\text { life: } \\
\text { 1. a reported } \\
\text { diagnosis by } \\
\text { the family } \\
\text { physician- } \\
\text { pediatrician; } \\
\text { 2. parental } \\
\text { reporting of } \\
\text { dry skin and } \\
\text { at least } 3 \text { of } 4 \\
\text { relevant } \\
\text { symptoms } \\
\text { (cheek } \\
\text { eczema, } \\
\text { eczema at } \\
\text { other sites, } \\
\text { infra-auricular } \\
\text { fissuring, and } \\
\text { scaly or itchy } \\
\text { rash for a } \\
\text { longer time } \\
\text { period); or } \\
\text { 3. visible AD } \\
\text { at skin } \\
\text { examination, } \\
\text { as defined } \\
\text { above) }\end{array}$ & $\begin{array}{l}\text { Population- } \\
\text { based birth } \\
\text { cohort }\end{array}$ & $\begin{array}{l}1314 \\
\text { children }\end{array}$ & $\begin{array}{l}\text { To } \\
\text { investigate } \\
\text { the natural } \\
\text { course of } \\
\text { AD } \\
\text { and to } \\
\text { analyze the } \\
\text { relationship } \\
\text { of AD } \\
\text { with } \\
\text { childhood } \\
\text { asthma. }\end{array}$ & $\begin{array}{l}\text { Risk factors of } \\
\text { AD persistance: } \\
\text { - initial } \\
\text { severity:OR 5.86 } \\
\text { [3.04-11.29] and } \\
\text { - atopic } \\
\text { sensitization } \\
\text { OR2.76[1.29- } \\
\text { 5.91] } \\
\text { Early wheeze and } \\
\text { a specific } \\
\text { sensitization } \\
\text { pattern: } \\
\text { significant } \\
\text { predictors for } \\
\text { wheezing at } \\
\text { school age, } \\
\text { irrespective of } \\
\text { AD. }\end{array}$ & $\begin{array}{l}\text { Children } \\
\text { with AD and } \\
\text { asthma } \\
\text { represents } \\
\text { a distinct } \\
\text { phenotype }\end{array}$ \\
\hline Ricci et al, & AD (Hanifin & Patient & 205 & To evaluate & Factors & Egg \\
\hline
\end{tabular}




\begin{tabular}{|c|c|c|c|c|c|c|}
\hline 2006 & \& Rajka) & cohort & children & $\begin{array}{l}\text { the natural } \\
\text { course of } \\
\mathrm{AD} \text { and the } \\
\text { factors } \\
\text { influencing } \\
\text { its healing or } \\
\text { persistence, } \\
\text { and the } \\
\text { appearance } \\
\text { of asthma }\end{array}$ & $\begin{array}{l}\text { significantly } \\
\text { associated with } \\
\text { asthma at } 6 \text { years } \\
\text { old: higher initial } \\
\text { severity of AD, } \\
\text { hen's egg } \\
\text { sensitization }\end{array}$ & $\begin{array}{l}\text { sensitization } \\
\text { is a particular } \\
\text { profile } \\
\text { amongst } \\
\text { children with } \\
\text { AD }\end{array}$ \\
\hline $\begin{array}{l}\text { van der } \\
\text { Hulst et } \\
\text { al, } 2007\end{array}$ & $\begin{array}{l}\text { Atopic } \\
\text { eczema } \\
\text { (criteria not } \\
\text { specified) }\end{array}$ & $\begin{array}{l}\text { Systematic } \\
\text { review }\end{array}$ & $\begin{array}{l}5384 \\
\text { children, } \\
13 \text { studies } \\
\text { (birth } \\
\text { cohorts, } \\
\text { outpatients } \\
\text { and } \\
\text { inpatients } \\
\text { studies) }\end{array}$ & $\begin{array}{l}\text { To assess } \\
\text { the } \\
\text { risk of } \\
\text { developing } \\
\text { asthma in } \\
\text { children } \\
\text { with atopic } \\
\text { eczema } \\
\text { during the } \\
\text { first } 4 \text { years } \\
\text { of life }\end{array}$ & $\begin{array}{l}\text { OR for asthma in } \\
\text { children with } \\
\text { atopic eczema: } \\
2.14 \text { [1.67-2.75] } \\
\text { Prevalence of } \\
\text { asthma at the age } \\
\text { of } 6 \text { years in } \\
\text { patients cohort } \\
\text { studies: approx. } \\
30 \%\end{array}$ & $\begin{array}{l}\text { Only } 1 \text { in } \\
\text { every } 3 \\
\text { children with } \\
\text { eczema } \\
\text { develops } \\
\text { asthma } \\
\text { during later } \\
\text { childhood }\end{array}$ \\
\hline $\begin{array}{l}\text { Lowe et } \\
\text { al, } 2008\end{array}$ & $\begin{array}{l}\text { Eczema } \\
\text { (parental } \\
\text { report of } \\
\text { either a doctor } \\
\text { diagnosis of } \\
\text { eczema or any } \\
\text { rash that was } \\
\text { treated with } \\
\text { topical steroid } \\
\text { preparation) }\end{array}$ & $\begin{array}{l}\text { High-risk } \\
\text { cohort }\end{array}$ & $\begin{array}{l}620 \\
\text { children }\end{array}$ & $\begin{array}{l}\text { To examine } \\
\text { the role of } \\
\text { infantile } \\
\text { eczema as a } \\
\text { predictor } \\
\text { of risk of } \\
\text { childhood } \\
\text { asthma }\end{array}$ & $\begin{array}{l}\text { Eczema within } \\
\text { the first } 2 \text { years of } \\
\text { life associated } \\
\text { with an increased } \\
\text { risk of childhood } \\
\text { asthma in boys: } \\
\text { OR } 2.45[1.31- \\
4.46] \text {, but not in } \\
\text { girls } \\
\text { OR } 0.88 \text { [0.43- } \\
1.77]\end{array}$ & $\begin{array}{l}\text { Eczema in } \\
\text { the first } 2 \\
\text { years of life } \\
\text { is associated } \\
\text { with } \\
\text { an increased } \\
\text { risk of } \\
\text { childhood } \\
\text { asthma in } \\
\text { boys, but } \\
\text { there is no } \\
\text { evidence of } \\
\text { this in girls. }\end{array}$ \\
\hline $\begin{array}{l}\text { von } \\
\text { Kobyletski } \\
\text { et al, } 2012\end{array}$ & $\begin{array}{l}\text { AD, eczema } \\
\text { (ISAAC) }\end{array}$ & $\begin{array}{l}\text { Population } \\
\text { based birth } \\
\text { cohort }\end{array}$ & $\begin{array}{l}3214 \\
\text { children }\end{array}$ & $\begin{array}{l}\text { To estimate } \\
\text { the } \\
\text { association } \\
\text { between } \\
\text { eczema in } \\
\text { early } \\
\text { childhood } \\
\text { and the } \\
\text { onset of } \\
\text { asthma and } \\
\text { rhinitis later } \\
\text { in life }\end{array}$ & $\begin{array}{l}\text { Risk of asthma : } \\
\text { - if AD: } \\
\text { OR3.07[1.795.27] } \\
\text { - if moderate to } \\
\text { severe AD :OR } \\
\text { 3.56[1.62-7.83] } \\
\text {-if early onset } \\
\text { AD: OR } \\
\text { 3.44[1.94-6.09] } \\
\text {-if persistent AD: } \\
\text { OR5.16[2.62- } \\
\text { 10.18] }\end{array}$ & $\begin{array}{l}\text { Eczema in } \\
\text { early } \\
\text { childhood is } \\
\text { strongly } \\
\text { associated } \\
\text { with the } \\
\text { development } \\
\text { of asthma }\end{array}$ \\
\hline $\begin{array}{l}\text { Saunes et } \\
\text { al, } 2012\end{array}$ & $\begin{array}{l}\text { Eczema } \\
\text { (ISAAC) }\end{array}$ & $\begin{array}{l}\text { Birth control } \\
\text { cohort of an } \\
\text { interventional } \\
\text { study }\end{array}$ & $\begin{array}{l}2192 \\
\text { children }\end{array}$ & $\begin{array}{l}\text { To study the } \\
\text { risk of } \\
\text { current } \\
\text { asthma and } \\
\text { the co- } \\
\text { existence of } \\
\text { allergy- } \\
\text { related } \\
\text { diseases at } 6 \\
\text { years } \\
\text { of age } \\
\text { among } \\
\text { children } \\
\text { with and }\end{array}$ & $\begin{array}{l}\text { Estimate for the } \\
\text { association } \\
\text { between eczema } \\
\text { at } 2 \text { years and } \\
\text { current asthma at } \\
6 \text { years: } \\
\text { OR=1.80[1.10- } \\
2.96]\end{array}$ & $\begin{array}{l}\text { Early eczema } \\
\text { is associated } \\
\text { with an } \\
\text { increased } \\
\text { risk of } \\
\text { developing } \\
\text { childhood } \\
\text { asthma. }\end{array}$ \\
\hline
\end{tabular}




\begin{tabular}{|c|c|c|c|c|c|c|}
\hline & & & & $\begin{array}{l}\text { without } \\
\text { eczema at } 2 \\
\text { years of age. }\end{array}$ & & \\
\hline $\begin{array}{l}\text { Carlsten } \\
\text { et al, } 2013\end{array}$ & $\begin{array}{l}\text { AD (presence } \\
\text { of a pruritic } \\
\text { rash on the } \\
\text { face or } \\
\text { extensor } \\
\text { surface of the } \\
\text { arms or legs } \\
\text { and flexural } \\
\text { lichenification } \\
\text { at the time of } \\
\text { examination } \\
\text { by the } \\
\text { allergist } \\
\text { investigators) }\end{array}$ & $\begin{array}{l}\text { High-risk } \\
\text { cohort }\end{array}$ & $\begin{array}{l}373 \\
\text { children }\end{array}$ & $\begin{array}{l}\text { To evaluate } \\
\text { the natural } \\
\text { history of } \\
\text { AD and its } \\
\text { association } \\
\text { with other } \\
\text { allergic } \\
\text { outcomes }\end{array}$ & $\begin{array}{l}\text { Risk of } \\
\text { sensitization to } \\
\text { aeroallergens at } 2 \\
\text { years if associated } \\
\text { AD: } \\
\text { OR2.97[1.25- } \\
7.08] \text { (non } \\
\text { persistent) and } \\
4.06 \text { [1.52-10.9] } \\
\text { (persistent) } \\
\text { Risk of asthma at } \\
7 \text { years if early- } \\
\text { onset persistent } \\
\text { AD: OR } \\
7.48[2.53-22.2] \\
\text { Non-significant } \\
\text { risk of } \\
\text { sensitization or } \\
\text { asthma if late- } \\
\text { onset }\end{array}$ & $\begin{array}{l}\text { Early-onset } \\
\text { persistent } \\
\text { AD is highly } \\
\text { associated } \\
\text { with atopic } \\
\text { sensitization } \\
\text { and } \\
\text { increases the } \\
\text { risk of atopic } \\
\text { diseases in } \\
\text { later } \\
\text { childhood }\end{array}$ \\
\hline $\begin{array}{l}\text { Silverberg } \\
\text { et al, } 2013\end{array}$ & $\begin{array}{l}\text { Eczema, AD } \\
\text { (if “Yes” to } \\
\text { the question: } \\
\text { "During the } \\
\text { past } 12 \\
\text { months, have } \\
\text { you been told } \\
\text { by a } \\
\text { doctor or } \\
\text { other health } \\
\text { professional } \\
\text { that (child) } \\
\text { had eczema or } \\
\text { any kind of } \\
\text { skin } \\
\text { allergy?”) }\end{array}$ & $\begin{array}{l}\text { National } \\
\text { survey }\end{array}$ & $\begin{array}{l}79667 \\
\text { children }\end{array}$ & $\begin{array}{l}\text { To } \\
\text { determine } \\
\text { the impact } \\
\text { of eczema } \\
\text { severity on } \\
\text { the } \\
\text { development } \\
\text { of other } \\
\text { comorbid } \\
\text { conditions }\end{array}$ & $\begin{array}{l}\text { Severe eczema } \\
\text { was associated } \\
\text { with a higher } \\
\text { prevalence of } \\
\text { comorbid } \\
\text { chronic health } \\
\text { disorders, } \\
\text { including asthma, } \\
\text { hay fever, and } \\
\text { food allergies } \\
(p<0.0001)\end{array}$ & $\begin{array}{l}\text { Severe } \\
\text { eczema is } \\
\text { associated } \\
\text { with multiple } \\
\text { comorbid } \\
\text { chronic } \\
\text { health } \\
\text { disorders, } \\
\text { impaired } \\
\text { overall } \\
\text { health, and } \\
\text { increased } \\
\text { healthcare } \\
\text { utilization }\end{array}$ \\
\hline $\begin{array}{l}\text { Nissen et } \\
\text { al, } 2013\end{array}$ & $\begin{array}{l}\text { Eczema } \\
\text { (Areas of } \\
\text { scaly, } \\
\text { erythematous } \\
\text { and itchy } \\
\text { eczematous } \\
\text { rash } \\
\text { primarily of } \\
\text { the face and } \\
\text { scalp, behind } \\
\text { the ears and at } \\
\text { the } \\
\text { flexural folds, } \\
\text { diagnosed by } \\
\text { a doctor. Only } \\
\text { eczema } \\
\text { localized to } \\
\text { at least two } \\
\text { typical areas } \\
\text { and } \\
\text { chronically }\end{array}$ & $\begin{array}{l}\text { Population- } \\
\text { based birth } \\
\text { cohort }\end{array}$ & $\begin{array}{l}276 \\
\text { children } \\
\text { (193 at the } \\
26 \text { years } \\
\text { follow-up) }\end{array}$ & $\begin{array}{l}\text { To } \\
\text { investigate } \\
\text { the natural } \\
\text { course of } \\
\text { sensitization } \\
\text { and allergic } \\
\text { diseases in a } \\
\text { random } \\
\text { population- } \\
\text { based } \\
\text { sample of } \\
\text { Danish } \\
\text { children }\end{array}$ & $\begin{array}{l}\text { Prevalence of } \\
\text { current eczema } \\
\text { stable during } \\
\text { childhood } \\
\text { Prevalence of } \\
\text { current eczema } \\
\text { decreased in } \\
\text { adulthood } \\
\text { Rates of } \\
\text { sensitization } \\
\text { increased from } \\
\text { childhood to } \\
\text { adulthood }\end{array}$ & $\begin{array}{l}\text { Allergic } \\
\text { diseases not } \\
\text { only occur in } \\
\text { childhood } \\
\text { but persist } \\
\text { into } \\
\text { adulthood. }\end{array}$ \\
\hline
\end{tabular}




\begin{tabular}{|c|c|c|c|c|c|c|}
\hline & $\begin{array}{l}\text { relapsing with } \\
\text { duration of at } \\
\text { least } 3 \text { months } \\
\text { were } \\
\text { recorded.) }\end{array}$ & & & & & \\
\hline $\begin{array}{l}\text { Eckbäck } \\
\text { et al, } 2014\end{array}$ & $\begin{array}{l}\text { Eczema } \\
\text { (Hanifin \& } \\
\text { Rajka) }\end{array}$ & $\begin{array}{l}\text { Patient } \\
\text { cohort }\end{array}$ & $\begin{array}{l}123 \\
\text { children }\end{array}$ & $\begin{array}{l}\text { To follow } \\
\text { infants with } \\
\text { eczema } \\
\text { and } \\
\text { suspected } \\
\text { food allergy } \\
\text { over time, } \\
\text { focusing on } \\
\text { sensitization } \\
\text { to } \\
\text { allergens, } \\
\text { severity of } \\
\text { eczema and } \\
\text { the } \\
\text { development } \\
\text { of allergic } \\
\text { airway } \\
\text { symptoms at } \\
4.5 \text { and } 10 \\
\text { years of age }\end{array}$ & $\begin{array}{l}\text { Higher SCORAD } \\
\text { on inclusion } \\
\text { correlated with } \\
\text { the risk of } \\
\text { developing } \\
\text { asthma: } \beta=10.17 \\
\text { ( } \mathrm{p}=0.01 \text { ) } \\
\text { If AD and } \\
\text { wheezing before } 2 \\
\text { years: OR for } \\
\text { developing } \\
\text { asthma } 4.05 \\
\text { ( } p=0.01 \text { ) }\end{array}$ & $\begin{array}{l}\text { Increased } \\
\text { risk of } \\
\text { asthma in } \\
\text { case of } \\
\text { severe AD } \\
\text { Increased } \\
\text { risk of } \\
\text { asthma if } \\
\text { concomitant } \\
\text { early-onset } \\
\text { AD and } \\
\text { wheezing }\end{array}$ \\
\hline $\begin{array}{l}\text { Amat et } \\
\text { al, } 2015\end{array}$ & $\begin{array}{l}\text { AD (UKWP } \\
\text { and ISAAC) }\end{array}$ & $\begin{array}{l}\text { Patient } \\
\text { cohort }\end{array}$ & $\begin{array}{l}217 \\
\text { children }\end{array}$ & $\begin{array}{l}\text { To define } \\
\text { early-onset } \\
\text { AD } \\
\text { phenotypes } \\
\text { leading to } \\
\text { asthma }\end{array}$ & $\begin{array}{l}\text { Three clusters: } \\
\text { - AD with low } \\
\text { sensitization } \\
\text { - AD with } \\
\text { multiple } \\
\text { sensitization } \\
\text { - AD with } \\
\text { familial history of } \\
\text { asthma } \\
\text { The two latter } \\
\text { associated with } \\
\text { higher frequency } \\
\text { of asthma at age } 6 \\
(\mathrm{p}<0.001)\end{array}$ & $\begin{array}{l}\text { Multiple } \\
\text { sensitization } \\
\text { and familial } \\
\text { history of } \\
\text { asthma } \\
\text { convey a } \\
\text { higher risk of } \\
\text { developing } \\
\text { asthma } \\
\text { during } \\
\text { childhood in } \\
\text { infants with } \\
\text { early-onset, } \\
\text { moderate to } \\
\text { severe AD. }\end{array}$ \\
\hline $\begin{array}{l}\text { Lee et al, } \\
2016\end{array}$ & AD (ISAAC) & $\begin{array}{l}\text { Patients from } \\
\text { a population- } \\
\text { based cohort }\end{array}$ & $\begin{array}{l}242 \\
\text { children }\end{array}$ & $\begin{array}{l}\text { To define } \\
\text { AD } \\
\text { phenotypes } \\
\text { in children } \\
\text { aged 6-8 } \\
\text { years }\end{array}$ & $\begin{array}{l}\text { Four phenotypes: } \\
\text { 'early onset with } \\
\text { low atopy' } \\
\text { ( } 26.4 \% \text { of the } \\
\text { sample; group 1) } \\
\text { 'early onset with } \\
\text { high atopy and } \\
\text { high eosinophil } \\
\text { percentages' } \\
\text { (48.3\%; group 2) } \\
\text { 'late onset with } \\
\text { low atopy' (9.9\%; } \\
\text { group 3) } \\
\text { 'late onset with } \\
\text { high atopy and } \\
\text { normal } \\
\text { eosinophils' } \\
\text { (15.3\%; group 4) } \\
\text { Persistence of } \\
\text { AD, eosinophilia }\end{array}$ & $\begin{array}{l}\text { An allergic } \\
\text { march- } \\
\text { associated } \\
\text { AD } \\
\text { phenotype } \\
\text { exists that is } \\
\text { characterized } \\
\text { by early- } \\
\text { onset, } \\
\text { persistent } \\
\text { AD and high } \\
\text { atopy. }\end{array}$ \\
\hline
\end{tabular}


and asthma

associated with

group 2

AD: atopic dermatitis; FS: food sensitization; FA: food allergy; PS: peanut sensitization; OR: odds ratio, 95\% confidence interval expressed [-]; PA: peanut allergy; UKWP: United Working Party Criteria; ISAAC: International Study of Asthma and Allergies in Childhood; TEWL: transepidermal water-loss; EPE: environmental peanut exposure

*Terms between brackets specify the criteria used to define AD

Figure 1 - Main risk factors involved in the atopic march 


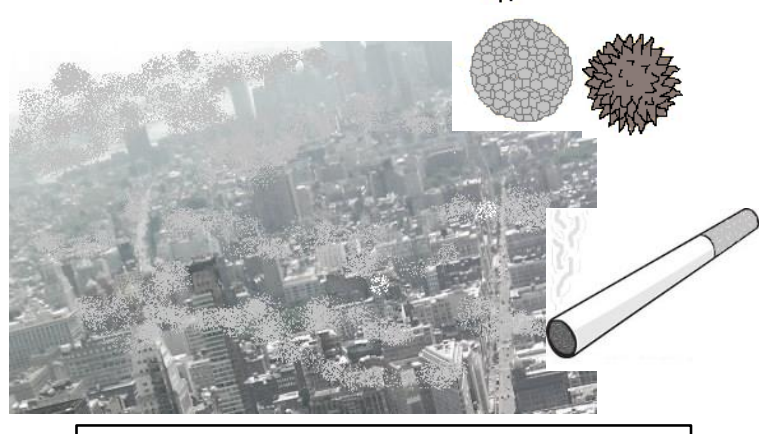

Environmental factors exposure:

pollutants/irritants, allergens...
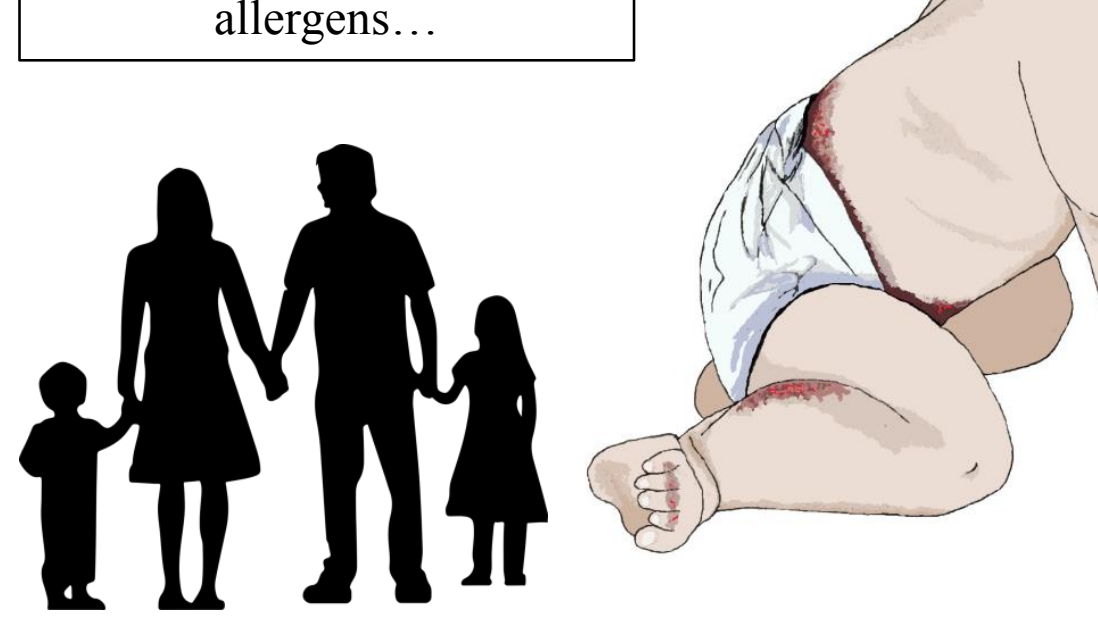

Male gender

Early-onset and severe atopic dermatitis
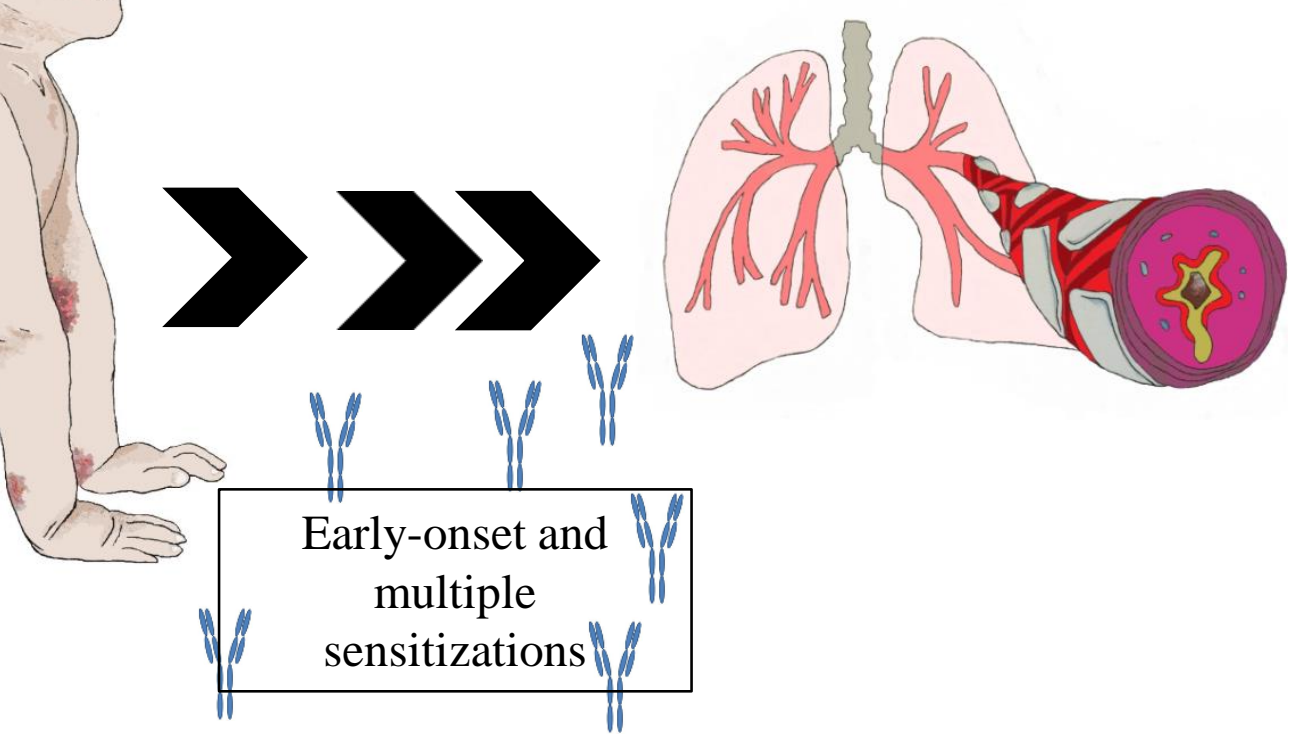

Familial history and genetic factors

Staphylococcus aureus toxins

\section{ATOPIC MARCH}


Table 1 - Terms used to identify studies focused on AD, adapted from Cochrane Skin Group guidelines

\begin{tabular}{lll}
\hline Definite AD & $\begin{array}{l}\text { Possible AD (AD retained if additional } \\
\text { features obtained in the original paper as a } \\
\text { good clinical description) }\end{array}$ & Not atopic eczema \\
\hline Atopic eczema & Childhood eczema & Seborrheic dermatitis/eczema \\
Atopic dermatitis & Infantile eczema & Contact dermatitis/eczema \\
& Eczema (unspecified) & Occupational dermatitis/eczema \\
& Dyshidrotic eczema & Hand dermatitis/eczema \\
& Nummular dermatitis & Allergic contact dermatitis/eczema \\
& Pityriasis alba & Irritant contact dermatitis/eczema \\
\hline
\end{tabular}


Table 2 - Main definitions for atopic dermatitis, atopic eczema and eczema

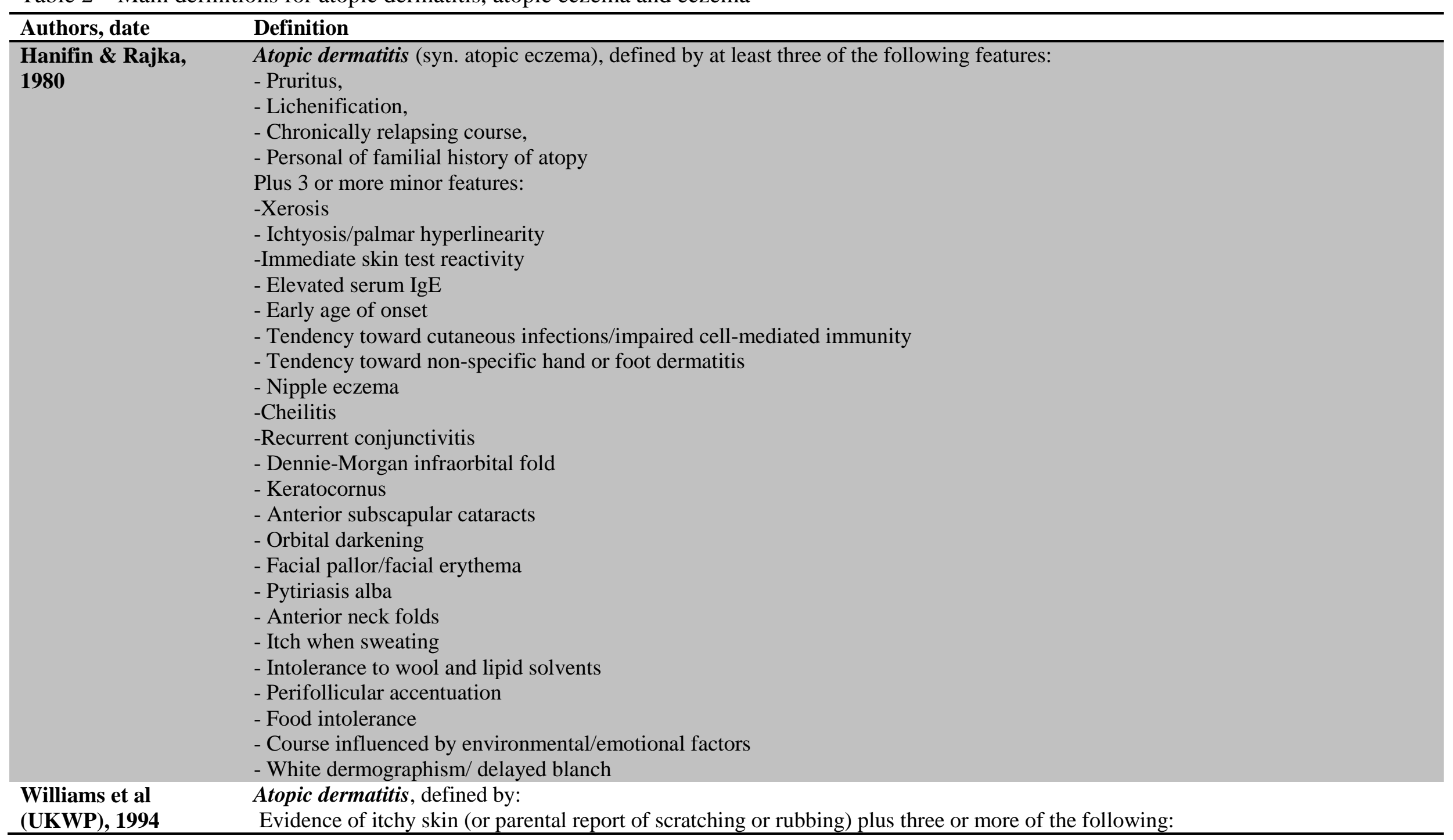


- History of involvement of the skin creases (e.g. fronts of elbows, backs of knees, fronts of ankles, and areas around the neck or eyes)

- History of asthma or hay fever (or history of atopic disease in a first-degree relative if the child is under four years of age)

- History of generally dry skin in the past year

- Onset in a child under 2 years of age (criterion not used if the child is under four years of age)

- Visible flexural dermatitis (including dermatitis affecting the cheeks or forehead and outer aspects of limbs in children under four years)

ISAAC Study Group, Current atopic eczema, defined if answered "Yes" to the questions:

1998 - "Have you ever had an itchy rash which was coming and going for at least 6 months? If yes:

- "Have you had this itchy rash at any time in the last 12 months?” If yes:

- "Has this itchy rash at any time affected any of the following places: the folds of the elbows, behind the knees, in front of the ankles, under the buttocks, or around the neck, ears, or eyes?"

UKWP: United Kingdom Working Party; ISAAC: International Study of Asthma and Allergies in Childhood 
Table 3 - Role of filaggrin variants in AD expression: summary of main results

\begin{tabular}{|c|c|c|c|c|c|c|}
\hline Authors, date & $\begin{array}{l}\text { Terms and } \\
\text { definitions } \\
\text { used* }\end{array}$ & Type of study & Population & Aim & Main results & Conclusions \\
\hline $\begin{array}{l}\text { Palmer et al, } \\
2006\end{array}$ & $\begin{array}{l}\text { AD, eczema } \\
\text { (UKWP) }\end{array}$ & $\begin{array}{l}\text { Case-control with } \\
\text { replication in } 2 \\
\text { population-based } \\
\text { cohorts }\end{array}$ & $\begin{array}{l}\text { Children } \\
189 \text { controls, } 52 \\
\text { cases with AD } \\
21 \text { cases with } \\
\text { AD + asthma } \\
\text { Replication: } \\
1008 \text { and } 604 \\
\text { subjects }\end{array}$ & $\begin{array}{l}\text { To assess the role of FLG } \\
\text { R501X and 2282del4 } \\
\text { variants in predisposition for } \\
\text { AD in Irish, Scottish and } \\
\text { Danish populations }\end{array}$ & $\begin{array}{l}\text { Risk of AD for carriers of at } \\
\text { least one allele: } \\
\text { - in Irish subjects: } \\
\text { OR13.4 [6.2-27.5] } \\
\text { - in Scottish subjects: } \\
\text { OR 1.8 [1.3-2.5] } \\
\text { - in Danish subjects: } \\
\text { HR 2.8 [1.7 - 4.5] }\end{array}$ & $\begin{array}{l}\text { Key } \\
\text { role of impaired skin barrier } \\
\text { function in the development of } \\
\text { atopic disease }\end{array}$ \\
\hline $\begin{array}{l}\text { Weidinger et al, } \\
2006\end{array}$ & AD (UKWP) & Family-based & 476 families & $\begin{array}{l}\text { To assess the role of R510X } \\
\text { and } \\
\text { 2282del } 4 \text { variants in } \\
\text { predisposition for AD }\end{array}$ & $\begin{array}{l}\text { Risk of AD while carrying } \\
\text { - 2282del4 variant: } \\
\text { OR 2.5[1.4-4.3] } \\
\text { - R501X variant: } \\
\text { OR 4.1[2.2-7.9] } \\
\text {-combined genotype: } \\
\text { OR 3.3[2.1-5.4] } \\
\text { Particular association with } \\
\text { "extrinsic” AD, characterized } \\
\text { by high total serum IgE levels } \\
\text { and concomitant allergic } \\
\text { sensitizations }\end{array}$ & $\begin{array}{l}\text { FLG is the first } \\
\text { really strong genetic factor } \\
\text { identified in a common } \\
\text { complex } \\
\text { disease } \\
\text { Crucial role } \\
\text { of the skin barrier in } \\
\text { preventing allergic } \\
\text { sensitization }\end{array}$ \\
\hline $\begin{array}{l}\text { Ruether et al, } \\
2006\end{array}$ & $\begin{array}{l}\text { AD (Hanifin } \\
\text { \& Rajka) }\end{array}$ & $\begin{array}{l}\text { Case-control and } \\
\text { family-based }\end{array}$ & $\begin{array}{l}\text { Children } \\
272 \text { cases } \\
276 \text { controls } \\
338 \text { families }\end{array}$ & $\begin{array}{l}\text { To explore further the } \\
\text { relevance of the variants in } \\
\text { Northern Germany }\end{array}$ & $\begin{array}{l}\text { Risk of AD while carrying } \\
\text { R501X variant: } \\
\text { OR 3.39 [1.75-6.58] } \\
\text { AD risk while carrying } \\
\text { 2282del4 variant = OR } 7.1 \\
\text { [3.41-14.78] }\end{array}$ & $\begin{array}{l}\text { FLG variants are specific to } \\
\text { the epidermal barrier, and are } \\
\text { major predisposing factors for } \\
\text { AD in Western European } \\
\text { populations }\end{array}$ \\
\hline $\begin{array}{l}\text { Nomura et al, } \\
2009\end{array}$ & $\begin{array}{l}\text { AD (not } \\
\text { specified) }\end{array}$ & Case-control & $\begin{array}{l}\text { Children and } \\
\text { adults } \\
118 \text { cases } \\
134 \text { controls }\end{array}$ & $\begin{array}{l}\text { To assess the link between } \\
\text { FLG mutations and AD in a } \\
\text { Japanese population }\end{array}$ & $\begin{array}{l}\text { Seven variants } \\
\text { described:R501X, 3321delA, } \\
\text { S1695X, Q1701X, S2554X, } \\
\text { S2889X, S3296X } \\
\text { Risk of AD if combined } \\
\end{array}$ & $\begin{array}{l}\text { FLG mutations are population- } \\
\text { specific }\end{array}$ \\
\hline
\end{tabular}




\begin{tabular}{|c|c|c|c|c|c|c|}
\hline & & & & & genotype: OR 6.8[2.5-18.5] & \\
\hline $\begin{array}{l}\text { Nemoto-Hasebe } \\
\text { et al, } 2009\end{array}$ & $\begin{array}{l}\text { AD (Hanifin } \\
\text { \& Rajka) }\end{array}$ & Case-control & $\begin{array}{l}\text { Adults } \\
24 \text { cases } \\
12 \text { controls }\end{array}$ & $\begin{array}{l}\text { Main hypothesis: skin barrier } \\
\text { defects caused by FLG } \\
\text { deficiency is a } \\
\text { primary abnormality leading } \\
\text { to the AD symptoms }\end{array}$ & $\begin{array}{l}\text { In filaggrin-related AD, } \\
\text { objective score of atopic } \\
\text { dermatitis correlated with } \\
\text { - TEWL } r=0.81, p<0.005 \\
\text { - SC hydration: } r=0.65, p<0.05 \\
\text { - SC thickness: } \\
\mathrm{r}=0.59, \mathrm{p}<0.05\end{array}$ & $\begin{array}{l}\text { Skin barrier defects due to } \\
\text { FLG mutations may play a } \\
\text { crucial role in the } \\
\text { pathogenesis of AD }\end{array}$ \\
\hline $\begin{array}{l}\text { Venkataraman } \\
\text { et al, } 2014\end{array}$ & $\begin{array}{l}\text { AD } \\
\text { (Hanifin \& } \\
\text { Rajka) }\end{array}$ & $\begin{array}{l}\text { Population-based } \\
\text { birth cohort }\end{array}$ & $\begin{array}{l}1313 \text { children at } \\
\text { the end of the } \\
\text { follow-up }\end{array}$ & $\begin{array}{l}\text { To explore the longitudinal } \\
\text { relationship between } 3 \\
\text { common FLG-LOF variants } \\
\text { and FA }\end{array}$ & $\begin{array}{l}\text { Effect of FLG-LOF variants } \\
\text { on the risk of FA: } \\
\text { - at } 10 \text { years: OR } 31.46 \text { [2.86- } \\
\text { >100 } \\
\text { - at } 18 \text { years: } 4.25[1.55-11.61] \\
\text { Indirect effect of FLG variants } \\
\text { on FA at all ages through } \\
\text { eczema and FS }\end{array}$ & $\begin{array}{l}\text { FLG-LOF mutations are } \\
\text { associated with FA in } \\
\text { older children through eczema } \\
\text { and FS during early childhood. } \\
\text { Biologically plausible pathway } \\
\text { suggesting that skin barrier } \\
\text { function is important in the } \\
\text { development and persistence } \\
\text { of FA. }\end{array}$ \\
\hline Ziyab et al, 2017 & $\begin{array}{l}\text { Eczema } \\
\text { (Hanifin \& } \\
\text { Rajka) }\end{array}$ & $\begin{array}{l}\text { Population-based } \\
\text { birth cohort }\end{array}$ & 94 children & $\begin{array}{l}\text { To assess whether FLG } \\
\text { expression in UCB } \\
\text { associates } \\
\text { with and predicts the } \\
\text { development of eczema in } \\
\text { infancy }\end{array}$ & $\begin{array}{l}\text { RR of eczema during the first } \\
\text { year of life if increased level of } \\
\text { FLG expression:0.60 [0.38- } \\
0.95] \\
\text { RR of eczema during the first } \\
\text { year of life if increased level of } \\
\text { FLG antisense transcripts : } \\
2.02[1.10-3.72]\end{array}$ & $\begin{array}{l}\text { FLG expression in UCB is } \\
\text { associated with eczema } \\
\text { development in infancy }\end{array}$ \\
\hline
\end{tabular}

AD: atopic dermatitis; UKWP: United Working Party Criteria; FLG: filaggrin; OR: odds ratio, 95\% confidence interval expressed [-]; HR: hazard ratio; TEWL: transepidermal water-loss; SC: subcutaneous; LOF: loss-of-function; RR: relative risk; UCB: umbilical cordon blood *Terms between brackets specify the criteria used to define $\mathrm{AD}$ 
Table 4 -Link between AD, food sensitization and food allergy: summary of main results

\begin{tabular}{|c|c|c|c|c|c|c|}
\hline $\begin{array}{l}\text { Authors, } \\
\text { date }\end{array}$ & Terms and definitions used* & Type of study & Population & Aim & Main results & Conclusions \\
\hline $\begin{array}{l}\text { Carlsten } \\
\text { et al, } 2013\end{array}$ & $\begin{array}{l}\text { AD (presence of a pruritic rash on the } \\
\text { face or extensor surface of the arms or } \\
\text { legs and flexural lichenification at the } \\
\text { time of examination by the allergist } \\
\text { investigators) }\end{array}$ & $\begin{array}{l}\text { High-risk } \\
\text { cohort }\end{array}$ & 373 children & $\begin{array}{l}\text { To evaluate the natural } \\
\text { history of } \mathrm{AD} \text { and its } \\
\text { association with other } \\
\text { allergic outcomes }\end{array}$ & $\begin{array}{l}\text { Risk of FS at } 2 \text { years if } \\
\text { associated AD: } \\
\text { OR } 2.52 \text { [1.11-5.74] (if } \\
\text { non persistent) } \\
\text { OR 5.92 [2.23-15.7] (if } \\
\text { persistent) } \\
\text { Risk of FA at } 7 \text { years if } \\
\text { early-onset persistent AD: } \\
\text { OR13.4[2.94-61.4] } \\
\text { Non significant risk of FS } \\
\text { or FA if late-onset }\end{array}$ & $\begin{array}{l}\text { Only early-onset, } \\
\text { persistent AD is } \\
\text { associated with atopic } \\
\text { sensitization }\end{array}$ \\
\hline $\begin{array}{l}\text { Du Toit et } \\
\text { al, } 2013\end{array}$ & $\begin{array}{l}\text { AD } \\
\text { (Hanifin \& Rajka) }\end{array}$ & $\begin{array}{l}\text { High-risk } \\
\text { cohort }\end{array}$ & 834 children & $\begin{array}{l}\text { To characterize a } \\
\text { population screened for } \\
\text { the risk of PA. }\end{array}$ & $\begin{array}{l}\text { PS was associated with } \\
\text { severe eczema: } \\
\text { OR } 2.47 \text { [1.14-5.34] }\end{array}$ & $\begin{array}{l}\text { Severe eczema } \\
\text { useful criterium for } \\
\text { identifying PA high-risk } \\
\text { infants }\end{array}$ \\
\hline $\begin{array}{l}\text { Gray et al, } \\
2014\end{array}$ & AD (UKWP) & Patient cohort & 100 children & $\begin{array}{l}\text { To determine } \\
\text { the prevalence of, and } \\
\text { risk factors for, IgE- } \\
\text { mediated FA in South } \\
\text { African } \\
\text { children with AD }\end{array}$ & $\begin{array}{l}66 \% \text { of associated FS } \\
40 \% \text { of associated FA: } \\
\text { egg } 25 \%, \text { PS } 24 \% \\
\text { Comparable FS rates } \\
\text { between Blacks and mixed } \\
\text { race patients, but lower PA } \\
\text { rates in Blacks } \\
\text { Risk factors for FA: early- } \\
\text { onset AD ( }<6 \text { months), } \\
\text { severe } \\
\text { eczema, and age }<2 \text { years }\end{array}$ & $\begin{array}{l}\text { Unexpectedly high } \\
\text { prevalence of FA in } \\
\text { South African } \\
\text { children with AD } \\
\text { Ethnic background } \\
\text { differences }\end{array}$ \\
\hline $\begin{array}{l}\text { Just et al, } \\
2015\end{array}$ & AD (UKWP and ISAAC) & Patient cohort & 229 children & $\begin{array}{l}\text { To describe the natural } \\
\text { history of sensitization } \\
\text { in a cohort of children } \\
\text { with early-onset AD }\end{array}$ & $\begin{array}{l}\text { FS decreased from } 58 \% \text { to } \\
34 \% \text { from } 1 \text { to } 6 \text { years } \\
\text { Risk of developing } \\
\text { sensitization to inhaled } \\
\text { allergens if initial multiple } \\
\text { FS: }\end{array}$ & $\begin{array}{l}\text { Multiple FS } \\
\text { conveys a higher risk of } \\
\text { sensitization to inhaled } \\
\text { allergens than single FS }\end{array}$ \\
\hline
\end{tabular}




\begin{tabular}{|c|c|c|c|c|c|c|}
\hline & & & & & OR 3.72 [1.68-8.30] & \\
\hline $\begin{array}{l}\text { Brough et } \\
\text { al, } 2015\end{array}$ & AD (Hanifin \& Rajka) & Patient cohort & 512 children & $\begin{array}{l}\text { To assess whether } \\
\text { EPE is a risk for PS and } \\
\text { PA }\end{array}$ & $\begin{array}{l}\text { Effect of EPE on PS: } \\
\text { - if history of AD: } \\
\text { OR 1.97 [1.26-3.09] } \\
\text { - if history of severe AD } \\
\text { OR } 2.41 \text { [1.30-4.47] } \\
\text { Effect of EPE on PA if } \\
\text { history of AD: } \\
\text { OR } 2.34 \text { [1.31-4.18] }\end{array}$ & $\begin{array}{l}\text { Exposure to peanut } \\
\text { antigen in dust through } \\
\text { an } \\
\text { impaired skin barrier in } \\
\text { atopic inflamed skin is a } \\
\text { plausible } \\
\text { route for PS and PA }\end{array}$ \\
\hline $\begin{array}{l}\text { Kelleher } \\
\text { et al, } 2016\end{array}$ & AD (UKWP) & $\begin{array}{l}\text { Population- } \\
\text { based birth } \\
\text { cohort }\end{array}$ & 1903 children & $\begin{array}{l}\text { To examine whether } \\
\text { early skin barrier } \\
\text { disruption, based on } \\
\text { TEWL assessment, is } \\
\text { associated with } \\
\text { increased rates of FS or } \\
\text { FA at } 2 \text { years of age. }\end{array}$ & $\begin{array}{l}\text { FS } 6.27 \% \\
\text { FA } 4.45 \% \\
\text { Egg: most prevalent } \\
\text { allergen }(2.94 \%) \text {, then } \\
\text { peanut }(1.75 \%) \text {, and cow's } \\
\text { milk }(0.74 \%) \\
\text { Day } 2 \text { TEWL }>9 \text { g } \\
\text { water/m²/h significant } \\
\text { predictor of FA at age } 2 \\
\text { years: OR } 4.1 \text { [1.5-4.8] }\end{array}$ & $\begin{array}{l}\text { Neonatal skin barrier } \\
\text { dysfunction predicts FA } \\
\text { at } \\
2 \text { years of age, } \\
\text { supporting the concept } \\
\text { of transcutaneous } \\
\text { allergen sensitization }\end{array}$ \\
\hline $\begin{array}{l}\text { Tsakok et } \\
\text { al, } 2016\end{array}$ & $\begin{array}{l}\text { AD, atopic eczema, eczema (exclusion } \\
\text { of sensitization-based } \mathrm{AD} \text { ) }\end{array}$ & $\begin{array}{l}\text { Systematic } \\
\text { review }\end{array}$ & $\begin{array}{l}\text { Children } \\
11 \\
\text { population- } \\
\text { based studies } \\
8 \text { high-risk } \\
\text { cohorts }\end{array}$ & $\begin{array}{l}\text { To review the } \\
\text { association between AD } \\
\text { and } \\
\text { FA, the effect of FA on } \\
\text { AD severity, chronicity, } \\
\text { and age of onset, } \\
\text { and the temporal } \\
\text { relationship between the } \\
\text { two. }\end{array}$ & $\begin{array}{l}\text { Likelihood of FS in } \\
\text { patients with AD } \\
\text { at } 3 \text { months of age = OR } \\
6.18 \text { [2.94-12.98] } \\
\text { Up to } 53 \% \text { of subjects with } \\
\text { AD had FS, and up to } 15 \% \\
\text { demonstrated FA in } \\
\text { population-based studies } \\
\text { Sixteen studies suggested } \\
\text { that FA is associated with } \\
\text { a more severe AD } \\
\text { phenotype } \\
\text { Six studies indicated that } \\
\text { AD of earlier onset or } \\
\text { increased persistence is } \\
\text { particularly associated } \\
\text { with FA }\end{array}$ & $\begin{array}{l}\text { Strong and } \\
\text { dose-dependent } \\
\text { association between } \\
\text { AD, food sensitization, } \\
\text { and } \\
\text { FA. } \\
\text { AD of increased } \\
\text { severity and chronicity } \\
\text { particularly } \\
\text { associated with FA } \\
\text { AD precedes the } \\
\text { development of food } \\
\text { sensitization and allergy }\end{array}$ \\
\hline
\end{tabular}


One study found that $\mathrm{AD}$

preceded the development

of FA.

AD: atopic dermatitis; FS: food sensitization; FA: food allergy; PS: peanut sensitization; OR: odds ratio, 95\% confidence interval expressed [-]; PA: peanut allergy; UKWP: United Working Party Criteria; ISAAC: International Study of Asthma and Allergies in Childhood; TEWL:

transepidermal water-loss; EPE: environmental peanut exposure.

*Terms between brackets specify the criteria used to define AD 
Table 5 - Link between AD and asthma: summary of main results

\begin{tabular}{|c|c|c|c|c|c|c|}
\hline $\begin{array}{l}\text { Authors, } \\
\text { date }\end{array}$ & Terms and definitions used* & Type of study & Population & Aim & Main results & Conclusions \\
\hline $\begin{array}{l}\text { Illi et al, } \\
2004\end{array}$ & $\begin{array}{l}\text { AD (at least one of the } \\
\text { following } 3 \text { criteria applied at } \\
\text { any follow-up visit in the first } \\
2 \text { years of life: } \\
\text { 1. a reported diagnosis by the } \\
\text { family physician-pediatrician; } \\
\text { 2. parental reporting of dry } \\
\text { skin and at least } 3 \text { of } 4 \\
\text { relevant } \\
\text { symptoms (cheek eczema, } \\
\text { eczema at other sites, infra- } \\
\text { auricular } \\
\text { fissuring, and scaly or itchy } \\
\text { rash for a longer time period); } \\
\text { or } \\
\text { 3. visible AD at skin } \\
\text { examination, as defined } \\
\text { above) }\end{array}$ & $\begin{array}{l}\text { Population- } \\
\text { based birth } \\
\text { cohort }\end{array}$ & 1314 children & $\begin{array}{l}\text { To investigate } \\
\text { the natural course of } \\
\mathrm{AD} \\
\text { and to analyze the } \\
\text { relationship of } \mathrm{AD} \\
\text { with childhood } \\
\text { asthma. }\end{array}$ & $\begin{array}{l}\text { Risk factors of AD } \\
\text { persistance: } \\
\text { - initial severity:OR } 5.86 \\
\text { [3.04-11.29] and } \\
\text { - atopic sensitization } \\
\text { OR2.76[1.29-5.91] } \\
\text { Early wheeze and a specific } \\
\text { sensitization pattern: } \\
\text { significant predictors for } \\
\text { wheezing at school age, } \\
\text { irrespective of AD. }\end{array}$ & $\begin{array}{l}\text { Children with } \mathrm{AD} \text { and } \\
\text { asthma represents } \\
\text { a distinct phenotype }\end{array}$ \\
\hline $\begin{array}{l}\text { Ricci et al, } \\
2006\end{array}$ & AD (Hanifin \& Rajka) & Patient cohort & 205 children & $\begin{array}{l}\text { To evaluate the } \\
\text { natural course of AD } \\
\text { and the factors } \\
\text { influencing its } \\
\text { healing or } \\
\text { persistence, and the } \\
\text { appearance of } \\
\text { asthma }\end{array}$ & $\begin{array}{l}\text { Factors significantly } \\
\text { associated with asthma at } 6 \\
\text { years old: higher initial } \\
\text { severity of AD, hen’s egg } \\
\text { sensitization }\end{array}$ & $\begin{array}{l}\text { Egg sensitization is a } \\
\text { particular profile amongst } \\
\text { children with AD }\end{array}$ \\
\hline $\begin{array}{l}\text { van der } \\
\text { Hulst et al, } \\
2007\end{array}$ & $\begin{array}{l}\text { Atopic eczema (criteria not } \\
\text { specified) }\end{array}$ & $\begin{array}{l}\text { Systematic } \\
\text { review }\end{array}$ & $\begin{array}{l}5384 \text { children, } \\
13 \text { studies (birth } \\
\text { cohorts, } \\
\text { outpatients and } \\
\text { inpatients }\end{array}$ & $\begin{array}{l}\text { To assess the } \\
\text { risk of developing } \\
\text { asthma in children } \\
\text { with atopic eczema } \\
\text { during the first } 4\end{array}$ & $\begin{array}{l}\text { OR for asthma in children } \\
\text { with atopic eczema: } 2.14 \\
\text { [1.67-2.75] } \\
\text { Prevalence of asthma at the } \\
\text { age of } 6 \text { years in patients }\end{array}$ & $\begin{array}{l}\text { Only } 1 \text { in every } 3 \\
\text { children with eczema } \\
\text { develops asthma during later } \\
\text { childhood }\end{array}$ \\
\hline
\end{tabular}




\begin{tabular}{|c|c|c|c|c|c|c|}
\hline & & & studies) & years of life & cohort studies: approx. 30\% & \\
\hline $\begin{array}{l}\text { Lowe et al, } \\
2008\end{array}$ & $\begin{array}{l}\text { Eczema (parental report of } \\
\text { either a doctor diagnosis of } \\
\text { eczema or any rash that was } \\
\text { treated with topical steroid } \\
\text { preparation) }\end{array}$ & High-risk cohort & 620 children & $\begin{array}{l}\text { To examine the role } \\
\text { of infantile eczema } \\
\text { as a predictor } \\
\text { of risk of childhood } \\
\text { asthma }\end{array}$ & $\begin{array}{l}\text { Eczema within the first } 2 \\
\text { years of life associated with } \\
\text { an increased risk of childhood } \\
\text { asthma in boys: OR } \\
2.45[1.31-4.46] \text {, but not in } \\
\text { girls } \\
\text { OR } 0.88 \text { [0.43-1.77] }\end{array}$ & $\begin{array}{l}\text { Eczema in the first } 2 \text { years } \\
\text { of life is associated with } \\
\text { an increased risk of } \\
\text { childhood asthma in boys, } \\
\text { but there is no } \\
\text { evidence of this in girls. }\end{array}$ \\
\hline $\begin{array}{l}\text { von } \\
\text { Kobyletski } \\
\text { et al, } 2012\end{array}$ & AD, eczema (ISAAC) & $\begin{array}{l}\text { Population based } \\
\text { birth cohort }\end{array}$ & 3214 children & $\begin{array}{l}\text { To estimate the } \\
\text { association between } \\
\text { eczema in early } \\
\text { childhood and the } \\
\text { onset of } \\
\text { asthma and rhinitis } \\
\text { later in life }\end{array}$ & $\begin{array}{l}\text { Risk of asthma : } \\
\text { - if AD: OR3.07[1.795.27] } \\
\text { - if moderate to severe AD } \\
\text { :OR 3.56[1.62-7.83] } \\
\text {-if early onset AD: OR } \\
\text { 3.44[1.94-6.09] } \\
\text {-if persistent AD: } \\
\text { OR5.16[2.62-10.18] }\end{array}$ & $\begin{array}{l}\text { Eczema in early childhood is } \\
\text { strongly associated } \\
\text { with the development of } \\
\text { asthma }\end{array}$ \\
\hline $\begin{array}{l}\text { Saunes et } \\
\text { al, } 2012\end{array}$ & Eczema (ISAAC) & $\begin{array}{l}\text { Birth control } \\
\text { cohort of an } \\
\text { interventional } \\
\text { study }\end{array}$ & 2192 children & $\begin{array}{l}\text { To study the risk of } \\
\text { current asthma and } \\
\text { the co-existence of } \\
\text { allergy-related } \\
\text { diseases at } 6 \text { years } \\
\text { of age among } \\
\text { children with and } \\
\text { without eczema at } 2 \\
\text { years of age. }\end{array}$ & $\begin{array}{l}\text { Estimate for the association } \\
\text { between eczema at } 2 \text { years } \\
\text { and current asthma at } 6 \text { years: } \\
\mathrm{OR}=1.80[1.10-2.96]\end{array}$ & $\begin{array}{l}\text { Early eczema is associated } \\
\text { with an increased risk of } \\
\text { developing childhood } \\
\text { asthma. }\end{array}$ \\
\hline $\begin{array}{l}\text { Carlsten et } \\
\text { al, } 2013\end{array}$ & $\begin{array}{l}\text { AD (presence of a pruritic } \\
\text { rash on the face or extensor } \\
\text { surface of the arms or legs } \\
\text { and flexural lichenification at } \\
\text { the time of examination by } \\
\text { the allergist investigators) }\end{array}$ & High-risk cohort & 373 children & $\begin{array}{l}\text { To evaluate the } \\
\text { natural history of } \\
\text { AD and its } \\
\text { association with } \\
\text { other allergic } \\
\text { outcomes }\end{array}$ & $\begin{array}{l}\text { Risk of sensitization to } \\
\text { aeroallergens at } 2 \text { years if } \\
\text { associated AD: OR2.97[1.25- } \\
7.08] \text { (non persistent) and } 4.06 \\
\text { [1.52-10.9] (persistent) } \\
\text { Risk of asthma at } 7 \text { years if } \\
\text { early-onset persistent AD: OR } \\
7.48[2.53-22.2] \\
\text { Non-significant risk of } \\
\text { sensitization or asthma if late- }\end{array}$ & $\begin{array}{l}\text { Early-onset persistent AD is } \\
\text { highly } \\
\text { associated with atopic } \\
\text { sensitization and increases } \\
\text { the risk of atopic diseases in } \\
\text { later childhood }\end{array}$ \\
\hline
\end{tabular}




\begin{tabular}{|c|c|c|c|c|c|c|}
\hline & & & & & onset & \\
\hline $\begin{array}{l}\text { Silverberg } \\
\text { et al, } 2013\end{array}$ & $\begin{array}{l}\text { Eczema, AD (if "Yes" to the } \\
\text { question: "During the past } 12 \\
\text { months, have you been told } \\
\text { by a } \\
\text { doctor or other health } \\
\text { professional that (child) had } \\
\text { eczema or } \\
\text { any kind of skin allergy?") }\end{array}$ & National survey & 79667 children & $\begin{array}{l}\text { To determine the } \\
\text { impact of eczema } \\
\text { severity on the } \\
\text { development of other } \\
\text { comorbid conditions }\end{array}$ & $\begin{array}{l}\text { Severe eczema was associated } \\
\text { with a higher prevalence of } \\
\text { comorbid } \\
\text { chronic health disorders, } \\
\text { including asthma, hay fever, } \\
\text { and food allergies } \\
(\mathrm{p}<0.0001)\end{array}$ & $\begin{array}{l}\text { Severe eczema is associated } \\
\text { with multiple comorbid } \\
\text { chronic health disorders, } \\
\text { impaired overall health, and } \\
\text { increased healthcare } \\
\text { utilization }\end{array}$ \\
\hline $\begin{array}{l}\text { Nissen et al, } \\
2013\end{array}$ & $\begin{array}{l}\text { Eczema (Areas of scaly, } \\
\text { erythematous and itchy } \\
\text { eczematous rash } \\
\text { primarily of the face and } \\
\text { scalp, behind the ears and at } \\
\text { the } \\
\text { flexural folds, diagnosed by a } \\
\text { doctor. Only eczema } \\
\text { localized to } \\
\text { at least two typical areas and } \\
\text { chronically relapsing with } \\
\text { duration of at least } 3 \text { months } \\
\text { were recorded.) }\end{array}$ & $\begin{array}{l}\text { Population- } \\
\text { based birth } \\
\text { cohort }\end{array}$ & $\begin{array}{l}276 \text { children } \\
\text { (193 at the } 26 \\
\text { years follow-up) }\end{array}$ & $\begin{array}{l}\text { To investigate the } \\
\text { natural course of } \\
\text { sensitization and } \\
\text { allergic diseases in a } \\
\text { random population- } \\
\text { based sample of } \\
\text { Danish children }\end{array}$ & $\begin{array}{l}\text { Prevalence of current eczema } \\
\text { stable during childhood } \\
\text { Prevalence of current eczema } \\
\text { decreased in adulthood } \\
\text { Rates of sensitization } \\
\text { increased from childhood to } \\
\text { adulthood }\end{array}$ & $\begin{array}{l}\text { Allergic diseases not only } \\
\text { occur in childhood but } \\
\text { persist into adulthood. }\end{array}$ \\
\hline $\begin{array}{l}\text { Eckbäck et } \\
\text { al, } 2014\end{array}$ & Eczema (Hanifin \& Rajka) & Patient cohort & 123 children & $\begin{array}{l}\text { To follow infants } \\
\text { with eczema } \\
\text { and suspected food } \\
\text { allergy over time, } \\
\text { focusing on } \\
\text { sensitization to } \\
\text { allergens, severity of } \\
\text { eczema and the } \\
\text { development of } \\
\text { allergic } \\
\text { airway symptoms at } \\
4.5 \text { and } 10 \text { years of } \\
\text { age }\end{array}$ & $\begin{array}{l}\text { Higher SCORAD on inclusion } \\
\text { correlated with the risk of } \\
\text { developing asthma: } \beta=10.17 \\
(p=0.01) \\
\text { If AD and wheezing before } 2 \\
\text { years: OR for developing } \\
\text { asthma } 4.05 \\
(p=0.01)\end{array}$ & $\begin{array}{l}\text { Increased risk of asthma in } \\
\text { case of severe AD } \\
\text { Increased risk of asthma if } \\
\text { concomitant early-onset AD } \\
\text { and wheezing }\end{array}$ \\
\hline Amat et al, & AD (UKWP and ISAAC) & Patient cohort & 217 children & To define early-onset & Three clusters: & Multiple sensitization and \\
\hline
\end{tabular}




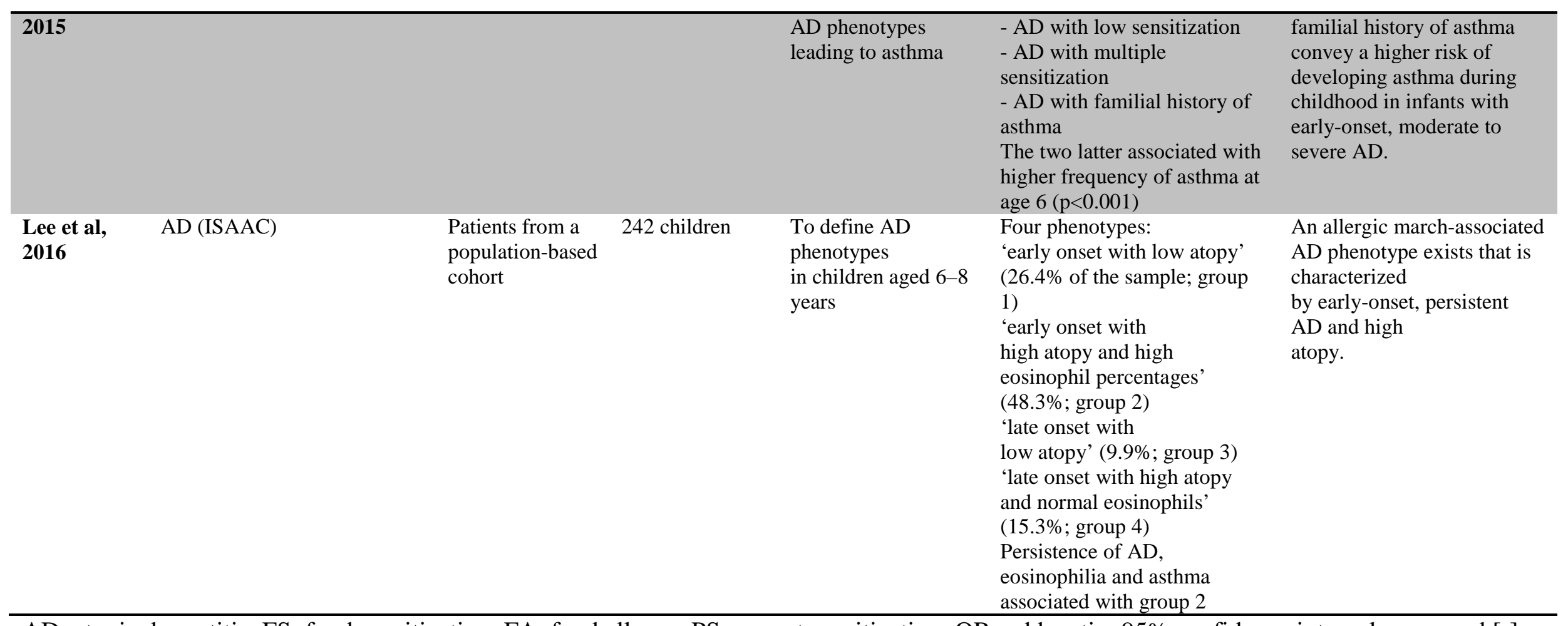

AD: atopic dermatitis; FS: food sensitization; FA: food allergy; PS: peanut sensitization; OR: odds ratio, 95\% confidence interval expressed [-]; PA: peanut allergy; UKWP: United Working Party Criteria; ISAAC: International Study of Asthma and Allergies in Childhood; TEWL:

transepidermal water-loss; EPE: environmental peanut exposure

*Terms between brackets specify the criteria used to define AD 